\title{
ANALISIS DAMPAK LALU LINTAS PEMBANGUNAN PASAR KEDUNGWUNI - KARANGDADAP, KABUPATEN PEKALONGAN
}

\author{
Pipit Rusmandani ${ }^{1}$, Muliani Chaerun Nisa ${ }^{2}$, Riandy S. Setiawan ${ }^{3}$ \\ ${ }^{1}$ Progam Studi Manajemen Keselamatan Transportasi Jalan \\ 2Progam Studi Manajemen Keselamatan Transportasi Jalan \\ 3Progam Studi Manajemen Keselamatan Transportasi Jalan \\ Politeknik Keselamatan Transportasi Jalan, Indonesia \\ Email: ${ }^{1}$ pipit@pktj.ac.id
}

\begin{abstract}
ABSTRAK
Analisis Dampak Lalu Lintas kini telah menjadi salah satu kebijakan strategis di Indonesia yang merupakan salah satu upaya yang dilakukan oleh pemerintah kota guna mengendalikan dampak yang ditimbulkan oleh pembangunan terhadap lalulintas di sekitarnya. Pada tahun 2018, Pemerintah Kabupaten Pekalongan melakukan Revitalisasi Pasar Kedungwuni yang kondisi fisiknya saat ini sudah tidak layak. Perkembangan jumlah pedagang dan pembeli serta semakin padatnya area distribusi dan sirkulasi di dalam pasar juga membutuhkan penataan pasar yang baik.

Namun karena pada dasarnya setiap rencana pembangunan atau pengembangan pusat kegiatan seperti seperti dalam hal ini adalah Revitalisasi Pasar Kedungwuni akan menimbulkan gangguan keamanan, keselamatan, ketertiban dan kelancaran lalulintas maka wajib dilakukan Analisis Dampak Lalu Lintas. Adapun area terdampak di sekitar lokasi ini meliputi tiga ruas jalan yaitu Jalan Karanganyar - Podo, Jalan Kedungwuni - Kutosari, Jalan Kedungwuni - Karangdadap dan tiga simpang (Simpang Podo merupakan simpang bersinyal serta Simpang Capgawen dan Simpang Eks BCA merupakan simpang tidak bersinyal).
\end{abstract}

Hasil Analisis Dampak Lalu Lintas akibat Revitalisasi Pasar Kedungwuni ini menujukkan bahwa kinerja ruas jalan eksisting untuk Jalan Karanganyar - Podo dan Jalan Kedungwuni - Kutosari adalah $\mathrm{C}$ dengan $\mathrm{V} / \mathrm{C}$ ratio masing-masing 0,52 dan 0,46 serta untuk Jalan Kedungwuni Karangdadap adalah $B$ dengan $\mathrm{V} / \mathrm{C}$ ratio 0,44 . Sedangkan ketiga simpang terdampak tergolong dalam tingkat pelayanan $\mathrm{B}$ dengan tundaan kurang dari 15 detik.

Pada tahap operasional tahun 2021 dengan pertumbuhan volume lalulintas sebesar 7\% per tahun, tingkat pelayanan ketiga ruas jalan mengalami penurunan menjadi kategori $\mathrm{F}$ dengan $\mathrm{V} / \mathrm{C}$ ratio $>1$ bahkan pada tahun $2031 \mathrm{~V} / \mathrm{C}$ rationya $>2$. Kondisi ini tentunya memerlukan penanganan agar kinerja lalulintasnya optimal. Adapun rekayasa lalulintas yang diusulkan adalah peningkatan kapasitas jalan dengan pelebaran jalan menjadi12 meter dengan median (4/2 D). Penanganan ini ternyata efektif dalam meningkatkan pelayanan kinerja jalan. Hal ini dapat ditunjukkan dari perubahan tingkat pelayanan jalan menjadi B pada tahun 2021 dan C pada tahun 2031. Sedangkan untuk kinerja simpang, pada tahap operasional sampai dengan tahun 2031 di Simpang Eks BCA dan Simpang Cap gawen diusulkan pemasangan APILL dengan 2 fase untuk menyelesaikan konflik lalulintas di simpang tersebut. Namun berbeda halnya dengan Simpang Podo, kondisi eksisting yang sudah menggunakan jenis pengendalian berupa APILL hanya efektif 
dilakukan sampai dengan tahun 2021. Selanjutnya saat tahun 2031 atau saat 10 tahun Pasar Kedungwuni beroperasi, APILL dirasa tidak efektif dan diusulkan untuk menggunakanB undaran (Rotary Intersection) sebagai penangannya.

Keyword : Andalalin, V/C ratio, pasar.

\section{PENDAHULUAN}

Pasar sebagai sarana perekonomian mempunyai fungsi sebagai sarana distribusi, pembentukan harga dan sebagai tempat ajang promosi. Dan pasar merupakan area tempat jual beli barang dengan jumlah penjual lebih dari satu baik yang disebut sebagai pusat perbelanjaan, pasar tradisional, pertokoan, mall, plasa, pusat perdagangan maupun sebutan lainnya.

Pada tahun 2018 terhadap Pasar Kedungwuni akan dilakukan Revitalisasi Pasar Kedungwuni, setiap rencana pembangunan atau pengembangan pusat kegiatan, permukiman dan infrastruktur yang akan menimbulkan gangguan keamanan, keselamatan, ketertiban dan kelancaran lalulintas dan angkutan jalan wajib dilakukan Analisis Dampak Lalu Lintas.

Analisis Dampak Lalu Lintas, untuk selanjutnya disebut Andalalin adalah studi/kajian mengenai dampak lalulintas dari suatu kegiatan dan/atau usaha tertentu yang hasilnya dituangkan dalam bentuk dokumen Andalalin atau Perencanaan Pengaturan Lalu Lintas. Hal ini dikaitkan bahwa setiap perubahan guna lahan akan mengakibatkan perubahan di dalam system transportasinya.

Pusat kegiatan yang baru akan menimbulkan bangkitan lalulintas dan mempengaruhi lalulintas yang ada di sekitar pusat kegiatan baru tersebut. Dengan adanya kegiatan Andalalin, maka dapat diperhitungkan seberapa besar bangkitan perjalanan baru yang memerlukan rekayasa lalulintas dan manajemen lalulintas untuk mengatasi dampaknya.

Pasar Kedungwuni Kabupaten Pekalongan dibangun pada tahun 1978, dengan jumlah pedagang saat ini mencapai 1.866 pedagang. Dalam perkembangannya, kondisi fisik dan lingkungan Pasar Kedungwuni saat ini cukup memprihatinkan, dimana kondisi fisik /bangunan pasar tersebut sudah tidak layak. Demikian pula sebagai akibat dari belum optimalnya penataan pasar tersebut, seiring dengan meningkatnya jumlah penjual/pedagang maupun pembeli/pengunjung maka area distribusi barang dan sirkulasi pembeli di dalam pasar sudah semakin padat. Demikian pula lain area bagi pejalan kaki/pembeli semakin habis dipergunakan untuk lokasi berjualan. Banyak juga pedagang yang menempati badan jalan sekitar lokasi pasar, sehingga hal ini menambah kesemrawutan kondisi pasar dan mengurangi ketertiban serta kebersihan lingkungan pasar.

Selanjutnya untuk meminimalkan terjadinya hambatan lalulintas sebagai akibat adanya pengembangan/revitalisasi Pasar Kedungwuni, maka perlu dilakukan studi berupa kajian teknis tentang dampak terhadap pengaruh kemacetan serta usulan berupa alternatef penanganan lalulintas dan keselamatan penggunajalan.

\section{LANDASAN TEORI}

Bangkitan dan Tarikan Perjalanan 
Tahapan awal dari 4 tahapan proses pemodelan (modelling) adalah Trip Production/Attraction (Bangkitan/Tarikan Perjalanan). Hasil dari tahapan ini berupa bangkitan perjalanan dan tarikan perjalanan untuk zona studi. Bangkitan lalulintas dari setiap zona dibentuk dengan mengambil asumsi adanya keterkaitan antara tata gunalahan dan kondisi system transportasi kawasan yang ada di dalam zona dengan besarnya perjalanan yang keluar masuk zona tersebut. Sebagai factor pembangkit perjalanan dapat diambil dari data sosioekonomi sedangkan faktor yang dianggap sebagai penarik perjalanan dapat diambil dari kondisi guna lahan, jumlah pekerja dan jumlah kegiatan (perdagangan, perkantoran dan lain sebagainya). Kondisi system transportasi kawasan juga mempengaruhi bangkitan perjalanan, dan biasanya ditentukan oleh jarak antar zona yang dikaji dengan pusat kota (CBD). Dengan mengambil asumsi adanya keterkaitan diantar afaktor-faktor tersebut diatas dengan jumlah perjalanan yang keluar masuk zona, maka akan ditentukan hubungan matematis yang akan menggambarkan tingkat bangkitan dan tarikan perjalanan dari zona tersebut. Model bangkitan perjalanan (produksi dan tarikanperjalanan) yang dikembangkan disesuaikan dengan perolehan data di lapangan. Pada dasarnya model ini dapat dikembangkan dengan persamaan linier maupun dengan suatu tingkat bangkitan pada setiap zona studi. Output dari proses bangkitan dan tarikan perjalanan ini adalah persamaan regresi dari bangkitan maupun tarikan perjalanan, yang akan dijadikan dasar untuk memprediksi bangkitan/tarikan perjalanan tiap zona yang ditetapkan. Data sekunder khususnya jumlah, Gross Floor Area (GFA) dan sosioekonomi akan dipadu dengan hasil survey traffic counting. Sehingga menghasilkan bangkitan dan tarikan perjalanan yang akurat.

\section{DistribusiPerjalanan}

Pengertian pemodelan trip distribution ini adalah penentuan asal dan tujuan perjalanan dari suatu zona ke zona-zona lainnya. Trip distribution pada intinya adalah tahapan untuk mendapatkan matrik asal tujuan (matrik O-D) yang akan digunakan dalam proses selanjutnya.

\section{PemilihanModa}

Dalam melaksanakan tahapan modal split, ada 2 macam konsep pendekatan, yaitu tripends modal split dan trip-interchange modal split. Trip-ends model digunakan untuk membagi total perjalanan orang menjadi perjalanan untuk masing-masing moda transportasi. Sedangkan trip-interchange model digunakan untuk memungkin kananalisi selebih lanjut perubahan pemilihan moda angkutan oleh karena perubahan karakteristik penyediaan (supply) transportasi dan kebijakan transportasi yang dikembangkan.

\section{PembebananPerjalanan}

Untuk keperluan pembebanan perjalanan, pada tahap ini matrik perjalanan orang dikonversi kedalam matrik perjalanan kendaraan dengan menggunakan pemuatan kendaraan yang didapatkan dari survey okupansi kendaraan. Proses ini adalah menganalisis penggunaan moda dalam melakukan perjalanan, khususnya diperlukan 
untuk melakukan penataan sarana maupun prasarana angkutan umum. Tahapanterakhiradalahtraffic assignment. Tahapan ini menghasilkan volume kendaraan di tiap ruas jalan. Pada proses assignment ini jumlah perjalanan antar zona yang sudah dibagi menurut penggunaan moda transportasinya dialokasikan kejaringan jalan. Dalam studi ini, penyusun membuat pembebanan dalam bentuk pembebanan perjalanan yang berfungsi untuk menetapkan rekomendasi perbaikan sarana dan prasarana transportasi, serta tindakan manajemen dan rekayasa lalu lintas.

Metode pembebanan lalu lintas ini bervariatif ragamnya, namun untuk pelaksanaan studi ini penyusun menggunakan metode pembebanan lalulintas dengan batasan kapasitas jalan(capacity restrained). Setelah proses pentahapan analisis tersebut akan menghasilkan kinerja lalulintas pada seluruh jaringan jalan dalam wilayah studi dengan indicator kinerja volume lalulintas, V/C ratio, kecepatan perjalanan dan tingkat pelayanan jalan(level of service/LOS). Langkah berikutnya adalah melakukan evaluasi kinerja lalulintas tersebut berdasarkan peraturan perundang-undangan yang berlaku, apakah nilai indicator kinerja lalulintasnya sudah memenuhi standar minimal yang disyaratkan atau tidak. Jika tidak maka perlu dilakukan perbaikan-perbaikan melalui tindakan manajemen dan rekayasa lalulintas pada lokasi-lokasi yang mengalami permasalahan setelah proses pemodelan lalulintas.

\section{KinerjaRuas Jalan}

kapasitas jalan, digunakan formulasi seperti yang tercantum dalam MKJI, 1997, sebagai berikut :

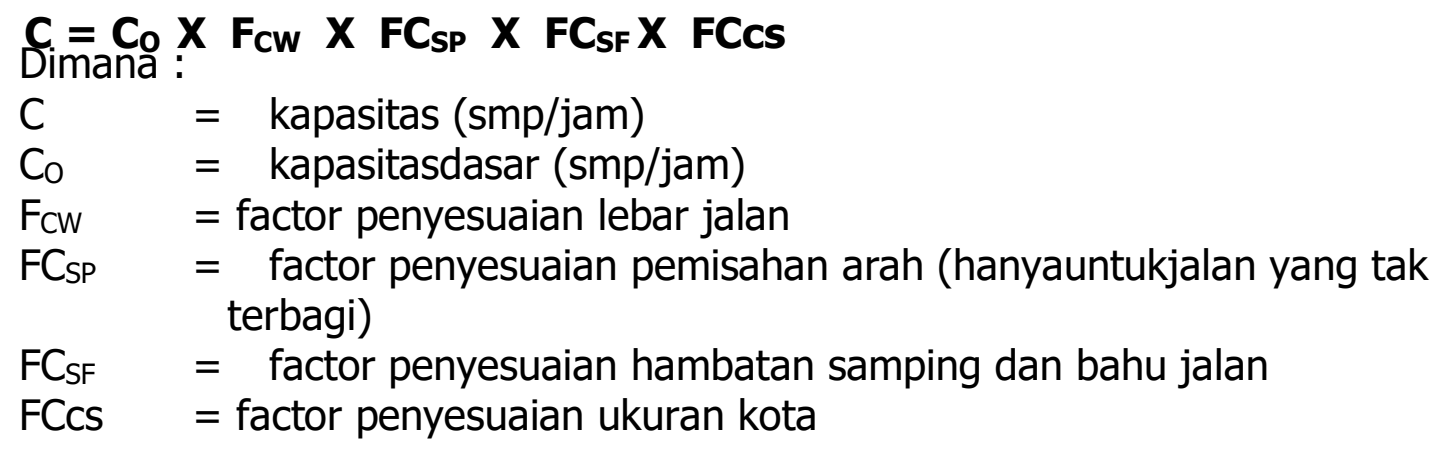

Masing-masing factor kembali diuraikan dengan ketentuan sesuai pada metode MKJI, sebagai berikut :

\section{Kapasitas Dasar (CO)}

Kapasitas dasar yang dipakai pada ruas jalan ini adalah sesuai dengan kapasitas dasar untuk ruas jalan dua lajurdua arah takterbagi (2/2 UD), sebagai berikut :

Tabel 1. Kapasitas Dasar

\begin{tabular}{|l|c|}
\hline $\begin{array}{c}\text { Tipe Jalan/ } \\
\text { TipeAlinyemen }\end{array}$ & $\begin{array}{c}\text { Kapasitas Dasar } \\
\text { Total } \\
\text { KeduaArahsmp/jam }\end{array}$ \\
\hline Dualajurtakterbagi & 3100 \\
- Datar & 3000 \\
- Bukit & 2900 \\
\hline
\end{tabular}




\section{Faktor Penvesuaian Terhadap Lebar Jalur Lalu Lintas (FCW)}

Faktor penyesuaian terhadap lebar jalan dapat mempergunakan table ini, sesuai dengan karakteristik yang diperoleh dari survey inventarisasi jalan.

Tabel 2. Faktor Penyesuaian Tehadap Lebar Jalan

\begin{tabular}{|c|c|c|}
\hline Tipe Jalan & $\begin{array}{l}\text { LebarEfektifJalurLalu Lintas(Wc) } \\
(\mathrm{m})\end{array}$ & FCW \\
\hline \multirow[t]{4}{*}{$\begin{array}{l}\text { Empatlajurterbagi } \\
\text { Enamlajurterbagi }\end{array}$} & $\begin{array}{l}\text { Per lajur } \\
30\end{array}$ & 0.91 \\
\hline & 3,25 & 0,96 \\
\hline & 3,50 & 1,00 \\
\hline & 3,75 & 1,03 \\
\hline \multirow[t]{4}{*}{ Empatlajurtakterbagi } & $\begin{array}{c}\text { Per lajur } \\
3.0\end{array}$ & 0.91 \\
\hline & 3,25 & 0,96 \\
\hline & 3,50 & 1,00 \\
\hline & 3,75 & 1,03 \\
\hline \multirow[t]{7}{*}{ Dualajurtakterbagi } & $\begin{array}{l}\text { Total keduaarah } \\
5\end{array}$ & 0.69 \\
\hline & 6 & 0,91 \\
\hline & 7 & 1,00 \\
\hline & 8 & 1,08 \\
\hline & 9 & 1,15 \\
\hline & 10 & 1,21 \\
\hline & 11 & 1,27 \\
\hline
\end{tabular}

\section{Faktor Penyesuaian Akibat Pemisahan Arah (FCSP)}

Faktor penyesuaian akibat pemisah arah, sesuai dengan metode MKJI dapat digunakan table sebagai berikut.

Tabel 3. Faktor Penyesuaian Akibat Pemisah Arah

\begin{tabular}{|l|l|c|c|c|c|c|}
\hline \multicolumn{2}{|c|}{ PemisahanArah SP \%-\% } & $\mathbf{5 0 - 5 0}$ & $\mathbf{5 5 - 4 5}$ & $\mathbf{6 0 - 4 0}$ & $\mathbf{6 5 - 3 5}$ & $\mathbf{7 0 - 3 0}$ \\
\hline \multirow{2}{*}{ FCSP } & Dualajur 2/2 & 1,00 & 0,97 & 0,94 & 0,91 & 0,88 \\
\cline { 2 - 7 } & Empatlaju 4/2 & 1,00 & 0,975 & 0,95 & 0,925 & 0,90 \\
\hline
\end{tabular}

Faktor penyesuaian akibat pemisahan arah ini tidak berlaku untuk ruas jalan dengan median, sehingga harus dimasukkan angka 1,0 untuk perhitungan.

Faktor Penyesuaian Akibat Hambatan Samping (FCSF) 
Faktor penyesuaian kapasitas akibat hambatan samping dapat dilihat pada table berikut ini.

Tabel 4. Faktor Penyesuaian Akibat Hambatan Samping

\begin{tabular}{|c|c|c|c|c|c|}
\hline \multirow{3}{*}{ Tipe Jalan } & \multirow{3}{*}{$\begin{array}{c}\text { Kelas } \\
\text { Hambatan } \\
\text { Samping }\end{array}$} & \multicolumn{4}{|c|}{$\begin{array}{l}\text { Faktor Penyesuaian Akibat } \\
\text { Hambatan Samping (FCSF) }\end{array}$} \\
\hline & & \multicolumn{4}{|c|}{ Lebar Bahu EfektifWs } \\
\hline & & $\leq 0,5$ & 1,0 & 1,5 & $\geq 2,0$ \\
\hline \multirow[t]{5}{*}{$4 / 2 D$} & $\mathrm{VL}$ & 0,99 & 1,00 & 1,01 & 1,03 \\
\hline & $\mathrm{L}$ & 0,96 & 0,97 & 0,99 & 1,01 \\
\hline & M & 0,93 & 0,95 & 0,96 & 0,99 \\
\hline & $\mathrm{H}$ & 0,90 & 0,92 & 0,95 & 0,97 \\
\hline & $\mathrm{VH}$ & 0,88 & 0,90 & 0,93 & 0,96 \\
\hline \multirow{5}{*}{$\begin{array}{l}2 / 2 \text { UD } \\
4 / 2 \text { UD }\end{array}$} & $\mathrm{VL}$ & 0,97 & 0,99 & 1,00 & 1,02 \\
\hline & $\mathrm{L}$ & 0,93 & 0,95 & 0,97 & 1,00 \\
\hline & M & 0,88 & 0,91 & 0,94 & 0,98 \\
\hline & $\mathrm{H}$ & 0,84 & 0,87 & 0,91 & 0,95 \\
\hline & $\mathrm{VH}$ & 0,80 & 0,83 & 0,88 & 0,93 \\
\hline
\end{tabular}

\section{Faktor Penvesuaian untuk Ukuran Kota (FCCS)}

Faktor penyesuaian untuk ukuran kota dapat dilihat pada table berikut.

Tabel 5. Faktor Penyesuaian untuk Ukuran Kota

\begin{tabular}{|c|c|}
\hline $\begin{array}{c}\text { Ukuran Kota } \\
\text { (JumlahPenduduk) }\end{array}$ & $\begin{array}{c}\text { FaktorPenyesuaianunt } \\
\text { ukUkuran Kota (FCC) }\end{array}$ \\
\hline$<0,1$ & 0,86 \\
\hline $0,1-0,5$ & 0,90 \\
\hline $0,5-1,0$ & 0,94 \\
\hline $1,0-3,0$ & 1,00 \\
\hline$>3$ & 1,04 \\
\hline
\end{tabular}

Analisa kecepatan dilakukan untuk mengetahui berapa kecepatan arus bebas di lokasi. Menurut metode MKJI, formulasinya adalah sebagai berikut :

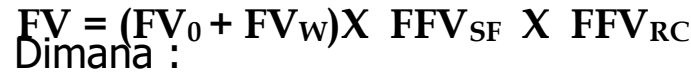

FV

= kecepatan arus bebas kendaraan ringan pada kondisi lapangan 
$\mathrm{FV}_{0}$

$\mathrm{FV}_{\mathrm{W}}$

FFV

FFV $(\mathrm{km} / \mathrm{jam})$

$=$ kecepatan arus bebas dasar kendaraan ringan $(\mathrm{km} / \mathrm{jam})$

$=$ factor penyesuaian untuk lebar efektif jalur lalulintas $(\mathrm{km} / \mathrm{jam})$

= factor penyesuaian untuk kondisi hambatan samping

$=$ factor penyesuaian untuk kelas fungsi jalan

Untuk menentukan tingkat pelayanan atau kineja suatu ruas jalanya itu dengan memproyeksikan nilai atau hasil analisis dari perbandingan $\mathrm{V} / \mathrm{C}$ ratio ruas. Sesuai dalam Manual Kapasitas Jalan Indonesia (MKJI) Tahun 1997, karakteristik tingkat pelayanan atau Level of Services (LOS) dapat dilihat pada tabelberikut.

Tabel 6. Karakteristik Tingkat Pelayanan

\begin{tabular}{|c|c|l|}
\hline $\begin{array}{c}\text { Tingkat } \\
\text { Pelayana } \\
\text { n } \\
\text { (LoS) }\end{array}$ & $\begin{array}{c}\text { Batas } \\
\text { Lingkup } \\
\text { V/C }\end{array}$ & \multicolumn{1}{|c|}{ Karakteristik } \\
\hline $\mathrm{A}$ & $0,00-0,20$ & $\begin{array}{l}\text { Kondisiarusbebasdengankecepatantinggi, } \\
\text { pengemudimemilihkecepatan yang } \\
\text { diinginkantanpahambatan. }\end{array}$ \\
\hline $\mathrm{B}$ & $0,21-0,44$ & $\begin{array}{l}\text { Arusstabil, tetapikecepatanoperasimulaidibatasi oleh } \\
\text { kondisilalulintas, pengemudimemilikikebebasan yang } \\
\text { cukupuntukmemilihkecepatan. }\end{array}$ \\
\hline $\mathrm{C}$ & $0,45-0,74$ & $\begin{array}{l}\text { Arusstabil, tetapikecepatan dan } \\
\text { gerakkendaraandikendalikan, } \\
\text { pengemudidibatasidalammemilihkecepatan. }\end{array}$ \\
\hline $\mathrm{D}$ & $0,75-0,84$ & $\begin{array}{l}\text { Arusmendekatitidakstabil, kecepatanmasihdikendalikan, } \\
\text { Q/C masihdapatditolerir. }\end{array}$ \\
\hline $\mathrm{E}$ & $0,85-1,00$ & $\begin{array}{l}\text { Volume lalulintasmendekati/berada pada } \\
\text { kapasitasarustidakstabil, terkadangberhenti. }\end{array}$ \\
\hline $\mathrm{F}$ & $>1,00$ & $\begin{array}{l}\text { Arus yang dipaksakan/macet, kecepatanrendah, V } \\
\text { diataskapasitas, antrianpanjang dan terjadihambatan- } \\
\text { hambatan yang besar. }\end{array}$ \\
\hline
\end{tabular}

\section{Sumber : Manual Kapasitas Jalan Indonesia (MKJI), 1997}

\section{Analisis Kinerja Simpang}

Simpang merupakan bagian yang tidak terpisahkan dari jaringan jalan. Di daerah perkotaan biasanya banyak memiliki simpang, dimana pengemudi harus memutuskan untuk berjalan lurus atau berbelok dan pindah jalan untuk mencapai satu tujuan. Simpang dapat didefinisikan sebagai daerah umum dimana dua jalan atau lebih bergabung atau bersimpangan, termasuk jalan dan fasilitas tepi jalan untuk pergerakan lalulintas di dalamnya. Untuk selanjutnya yang akan dibahas dalam sub bab ini adalah simpang tak bersinyal sesuai dengan kondisi eksisting yang ditemui pada lokasi studi. Ukuran-ukuran kinerja simpang tak bersinyal pada umumnya dinyatakan dalam kapasitas, derajat kejenuhan, tundaan dan peluangantrian.

\section{Kapasitas}


Kapasitas adalah arus lalulintas maksimum yang dapat dipertahankan (tetap) pada suatu bagian jalan dalam kondisi tertentu dinyatakan dalam kendaraan/jam atau smp/jam. Kapasitas total suatu persimpangan dapat dinyatakan sebagai hasil perkalian antara kapasitas dasar (Co) dan faktor-faktor penyesuaian (F). Rumusan kapasitas simpang menurut MKJI 1997 sebagaiberikut :

Dimana :

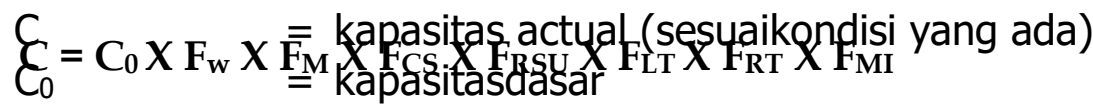

$\mathrm{F}_{\mathrm{W}} \quad=$ factor penyesuaian lebar masuk

$\mathrm{F}_{\mathrm{M}} \quad=$ factor penyesuaian median jalanutama

F $\quad=$ factor penyesuaian ukuran kota

F $\quad=$ factor penyesuaian tipe lingkungan jalan, hambatansamping dan kendaraan tak bermotor

$\mathrm{F}_{\mathrm{LT}} \quad=$ factor penyesuaian rasio belok kiri

$\mathrm{F}_{\mathrm{RT}} \quad=$ factor penyesuaian rasio belok kanan

$\mathrm{F}_{\mathrm{MI}}=$ factor penyesuaian rasio arus jalan minor

\section{Derajat Kejenuhan}

Derajat Kejenuhan (DS) merupakan rasio arus lalulintas (smp/jam) terhadap kapasitas (smp/jam) dan dapat ditulis dengan persamaan sebagai berikut :

\section{DS $=Q_{\text {smp }} / \mathbf{C}$}

Dimana :

DS $\quad=$ derajat kejenuhan

C $\quad=$ kapasitas (smp/jam)

Qsmp = arus total sesungguhnya (smp/jam), dihitung sebagai berikut:

$$
\mathrm{Q}_{\mathrm{smp}}=\mathrm{Q}_{\text {kend. }} . X \mathrm{~F}_{\mathrm{smp}}
$$

$\mathrm{F}_{\text {smp }}$ merupakan factor ekivalen mobil penumpang (emp)

\section{Tundaan}

Tundaan di persimpangan adalah total waktu hambatan rata-rata yang dialami oleh kendaraan sewaktu melewati suatu simpang. Hambatan tersebut muncul jika kendaraan berhenti karena terjadinya antrian di simpang sampai kendaraan itu keluar dari simpang karena adanya pengaruh kapasitas simpang yang sudah tidak memadai. Nilai tundaan mempengaruhi nilai waktu tempuh kendaraan. Semakin tinggi nilai tundaan, semakin tinggi pula waktu tempuh.

a) Tundaan lalulintas rata-rata untuk seluruh simpang (DTi

Tundaan lalulintas rata-rata $\mathrm{DT}_{\mathrm{i}}$ (detik/smp) adalah tundaan rata-rata untuk seluruh kendaraan yang masuk simpang. Tundaan DTiditentukan dari hubungan empiris antara tundaan $\mathrm{DT}_{i}$ dan deraja tkejenuhan (DS).

- Untuk DS $\leq 0,6$ : 


$$
D T_{i}=2+(8,2078 \times D S)-[(1-D S) \times 2]
$$

- Untuk DS > 0,6 :

$$
\mathrm{DT}_{\mathrm{i}}=\frac{1,0504}{[0,2742-(0,2042 \times \mathrm{DS})]}-[(1-\mathrm{DS}) \times 1,8]
$$

b) Tundaan lalulintas rata-rata untuk jalan major (DTMA)

Tundaan lalulintas rata-rata untuk jalan mayor merupakan tundaan lalulintas ratarata untuk seluruh kendaraan yang masuk di simpang melalui jalan major.

- Untuk DS $\leq 0,6$ :

$$
\mathrm{DT}_{\mathrm{MA}}=1,8+(5,8234 \times \mathrm{DS})-[(1-\mathrm{DS}) \times 1,8]
$$

- Untuk DS > 0,6 :

$$
\mathrm{DT}_{\mathrm{MA}}=\frac{1,05034}{[0,346-(0,246 \times \mathrm{DS})]}-[(1-\mathrm{DS}) \mathrm{x} 1,8]
$$

c) Tundaan lalulintas rata-rata untuk jalan minor (DT $\mathrm{MI}_{\mathrm{M}}$ )

Tundaanlalulintas rata-rata jalan minor ditentukan berdasarkan tundaan lalulintas rata-rata $\left(\mathrm{DT}_{\mathrm{i}}\right)$ dan tundaan lalulintas rata-rata jalan major (DT $\mathrm{MA}_{\mathrm{A}}$ ).

$$
\mathrm{DT}_{\mathrm{MI}}=\frac{\left[\left(\mathrm{Q}_{\mathrm{smp}} \times \mathrm{DT}_{\mathrm{i}}\right)-\left(\mathrm{Q}_{\mathrm{MA}} \times \mathrm{DT}_{\mathrm{MA}}\right)\right]}{\mathrm{Q}_{\mathrm{MI}}}
$$

Dimana :

Qsmp = arus total sesungguhnya (smp/jam)

Q $\quad=$ jumlah kendaraan yang masuk di simpang melalui jalan major (smp/jam)

Q $\quad=$ jumlah kendaraan yang masuk di simpang melalui jalan minor (smp/jam)

d) Tundaan geometri ksimpang (DG)

Tundaan geometric simpang adalah tundaan geometrik rata-rata seluruh kendaraan bermotor yang masuk di simpang. DG dihitung menggunakan persamaan :

- Untuk DS $\leq 1,0$ :

$$
D G=(1-D S) \times\left(P_{T} \times 6+\left(1-P_{T}\right) \times 3\right)+D S \times 4
$$

- Untuk DS > 0,6 :

$$
\mathrm{DG}=4 \text { detik/smp }
$$

e) Tundaan simpang (D)

Tundaan simpang dihitung menggunakan persamaan sebagai berikut :

$$
\mathrm{D}=\mathrm{DG}+\mathrm{DT}
$$

\section{Peluang Antrian}

Batas nilai peluang antrian QP\% (\%) ditentukan dari hubungan empiris antara peluang antrian QP\% dan derajat kejenuhan DS. Peluang antrian dengan batas atas dan batas bawah dapat diperoleh dengan menggunakan rumus sebagai berikut di bawah ini : 
Batas atas $\quad \mathrm{QPa}=(47,71 \times \mathrm{DS})-\left(24,68 \times \mathrm{DS}^{2}\right)+\left(56,47 \times \mathrm{DS}^{2}\right)$

Batas bawah $\mathrm{QPb}=(9,02 \times \mathrm{DS})+\left(20,66 \times \mathrm{DS}^{2}\right)+\left(10,49 \times \mathrm{DS}^{2}\right)$

Sedangkan menurut Tamin (2000), tingkat pelayanan atau kinerja suatu persimpangan didasarkan pada nilai lama tundaan per kendaraan. Untuk lebih jelasnya dapat dilihat pada table sebagai berikut.

Tabel 7. Indeks Tingkat Pelayanan (ITP) Lalu Lintas di Persimpan
\begin{tabular}{c|c|}
$\begin{array}{c}\text { Indeks Tingkat } \\
\text { Pelayanan }\end{array}$ & $\begin{array}{c}\text { Tundaan per Kendaraan } \\
\text { (detik) }\end{array}$ \\
\hline A & $\leq 5,0$ \\
\hline B & $5,1-15,0$ \\
\hline C & $15,1-25,0$ \\
\hline D & $25,1-40,0$ \\
\hline E & $40,1-60,0$ \\
\hline F & $>60,0$ \\
\hline
\end{tabular}

Sumber :Perencanaan dan PermodelanTransportasi, Tamin, 2000

\section{METODE PENELITIAN}

Ruang Lingkup kajian Analisis Dampak Lalu Lintas Pembangunan Pasar Kedungwuni ini ruas jalan terdampak meliputi ruas Jalan Kedungwuni - Karangdadap, Jalan Kedungwuni - Kutosari dan Jalan Karanganyar - Podo. Sedangkan tiga simpang terdampak di sekitar Pasar Kedungwuni meliputi Simpang Capgawen, Simpang Eks BCA dan Simpang Podo.Sebagai mana diterangkan dalam gambar berikutini :

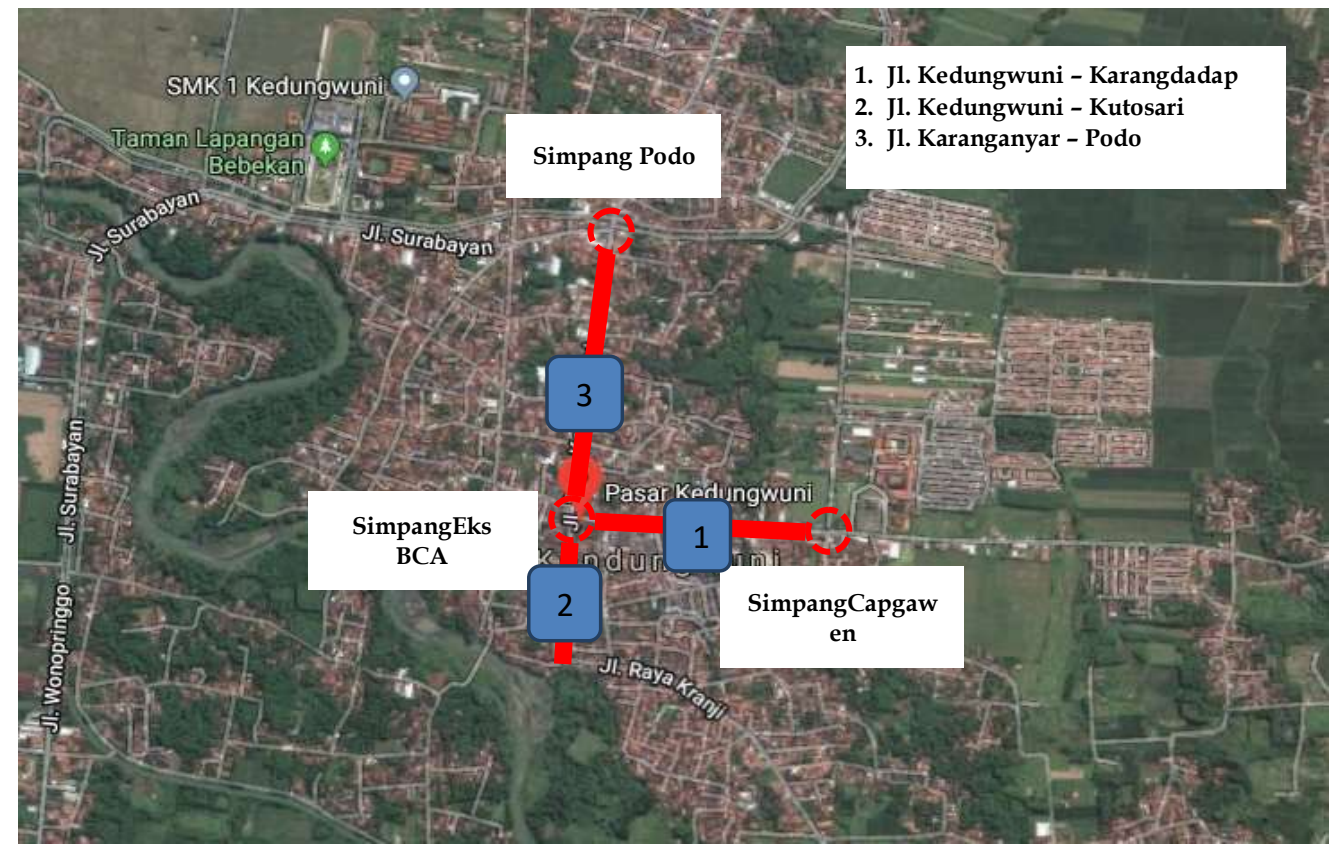

Gambar 1. Lokasi Studi

Metodologi pengumpulan

data pada kajian analisis dampak lalulintas pembangunan Pasar Kedungwuni, metodologi dalam pengambilan data dibagi dalam 2 (dua) tahapan yaitu data primer dan data sekunder. Data primer yang dikumpulkan dari yaitu survey 
tarikan-bangkitan perjalanan, survey inventarisasi jalan, survey traffic counting dan survey kecepatan perjalanan. Metodologi komprehensif yang disusun dimulai dengan tahap pengumpulan data, dalam hal ini data sekunder. Data-data yang dikumpulkan dalam tahap ini berupa identifikasi terhadap 4 (empat) masalah pokok, yaitu :Data operasional, Data Administratif, Data jaringan jalan dan tata guna lahan yang sudah ada (eksisting), Data rancangbangun dan lay out (master plan).

Penyusunan metodologi yang disampaikan dalam kajian ini langsung ditekankan pada tujuan utama untuk mengetahui sejauh mana dampak pembangunan Pasar Kedungwuni terhadap lalulintas sekitar. Metodologi yang digunakan dalam studi ini diharapkan mampu memadukan seluruh proses pekerjaan. Secara umum metodologi penelitian yang disusun pada dokumen Analisis Dampak Lalu Lintas Pembangunan Pasar Kedungwuni dapat dilihat pada diagram pada gambar2 berikut :

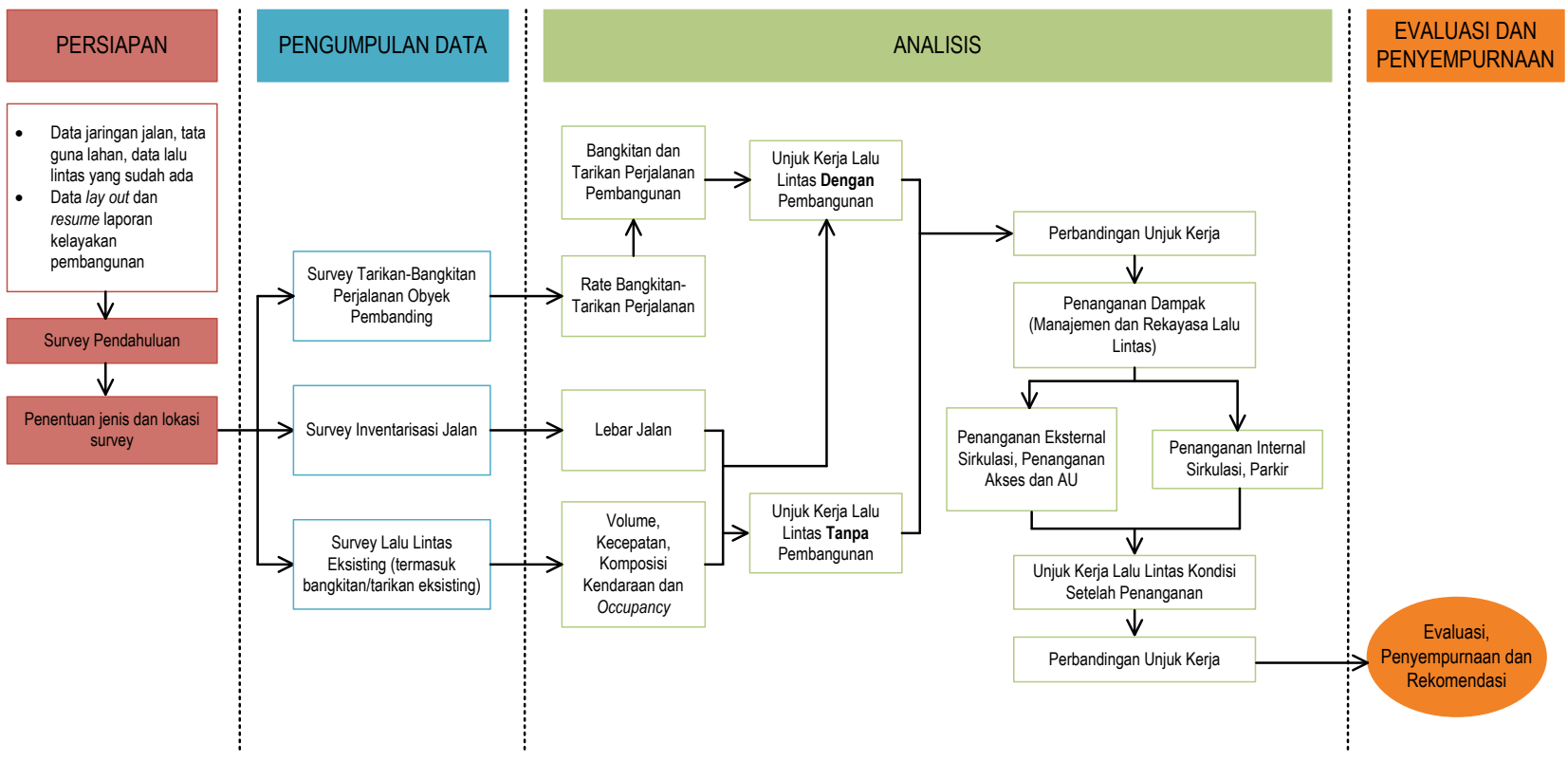

Gambar 2. Metodologi Penelitian

Metode Analisis pada tahapan ini dilakukan kompilasi data dan analisis dalam rangka analisis besaran dan luasan dampak serta penanganan dampak yang dilakukan. Analisis yang dilakukan yaitu Pengembangan Model, Analisis Kinerja Ruas Jalan, Analisis Kinerja Simpang, Analisis Penanganan Dampak, Rekomendasi.

\section{Pengembangan Model}

Dalam melakukan kajian analisis dampak lalulintas terutama dalam rangka melakukan permodelan kinerja lalulintas pada saat konstruksi maupun pada saat setelah terbangun, maka penggunaan model transportasi harus digunakan dalam hal ini. Terkait dengan hal tersebut diatas, penyusun akan menggunakan permodelan transportasi 4 tahap, yaitu bangkitan dan tarikan perjalanan, distribusi perjalanan, pemilihan moda dan pembebanan lalulintas. 


\section{Analisis Kinerja Ruas Jalan}

Dilakukan baik tanpa pembangunan maupun dengan pembangunan. Hal ini dilakukan untuk mengetahui dan memahami permasalahan transportasi dan lalulintas pada daerah studi. Analisis kinerja jaringan yang dilakukan oleh penyusun disini terdiri atas analisis kinerja ruas jalan daerah eksternal dan analisis antrian pada jalan akses. Oleh karena itu dalam analisis kinerja jaringan eksisting ini, parameter yang digunakan antara lain adalah nisbah volume-kapasitas(V/C ratio), derajat kejenuhan (degree of saturation), Panjang antrian(queue) dan besar hambatan(delay).

\section{Analisis Kinerja Simpang,}

Simpang merupakan bagian yang tidak terpisahkan dari jaringan jalan. Di daerah perkotaan biasanya banyak memiliki simpang, dimana pengemudi harus memutuskan untuk berjalan lurus atau berbelok dan pindah jalan untuk mencapai satu tujuan. Simpang dapat didefinisikan sebagai daerah umum dimana dua jalan atau lebih bergabung atau bersimpangan, termasuk jalan dan fasilitas tepi jalan untuk pergerakan lalulintas di dalamnya. Untuk selanjutnya yang akan dibahas adalah simpang tak bersinyal sesuai dengan kondisi eksisting yang ditemui pada lokasi studi. Ukuran-ukuran kinerja simpang tak bersinyal pada umumnya dinyatakan dalam kapasitas, derajat kejenuhan, tundaan dan peluang antrian.

\section{Analisis Penanganan Dampak,}

Tahapan analisis penanganan dampak adalah tahapan dimana skema yang diusulkan dikaji efektifitasnya dengan parameter mikro rekayasa lalulintas. Analisis yang dilakukan terdiri dari analisis jaringan jalan eksternal lokasi dan analisis internal lokasi.Kajian eksternal lokasi meliputi kajian terhadap usulan penanganan ruas jalan serta penyediaan fasilitas pejalan kaki. Sedangkan analisis internal lokasi ditekankan pada kajian usulan akses keluar - masuk serta parkir.

Rekomendasi terhadap alternative penanganan dampak terbaik yang disampaikan dengan dilengkapi rencana teknik manajemen lalulintas dan manajemen kebutuhan yang direkomendasikan.

\section{HASIL DAN PEMBAHASAN}

\section{Analisis Bangkitan dan Tarikan Perjalanan}

Tahun 2018, merupakan tahun dasar dimana kondisi Pasar Kedungwuni benar-benarreal time yaitu sebelum masa pembangunan dan penataan pasar. Dengan demikian maka belum terjadi perubahan di Jalan Karanganyar - Podo, Jalan Kedungwuni - Kutosari dan Jalan Kedungwuni - Karangdadap. Gambaran data lalulintas pada ruas jalan terkena dampak tersebut secara lengkap dijelaskan pada table berikut.

Tabel 8. DistribusiPerjalananTahun 2018 (Eksisting) (kend./hari) 
Sumber : Hasil Analisis

\begin{tabular}{|c|c|c|c|c|c|c|c|}
\hline & & \\
\hline & & 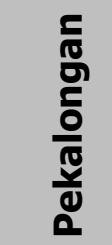 & 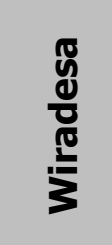 & $\begin{array}{l}\text { 옹 } \\
\text { 음 }\end{array}$ & 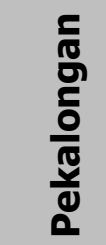 & ס & \\
\hline & O/D & 1 & 2 & 3 & 4 & 5 & $\mathrm{Pj}$ \\
\hline Pekalongan & 1 & 0 & 387 & 177 & 410 & 385 & 1360 \\
\hline Wiradesa & 2 & 833 & 0 & 63 & 163 & 248 & 1207 \\
\hline Doro & 3 & 435 & 128 & 0 & 137 & 193 & 893 \\
\hline Pekalongan & 4 & 664 & 277 & 241 & 0 & 463 & 1646 \\
\hline Batang & 5 & 667 & 432 & 243 & 563 & 0 & 1905 \\
\hline & $\mathrm{Aj}$ & 2599 & 1224 & 724 & 1274 & 1289 & 7111 \\
\hline
\end{tabular}

Berdasarkan table diatas diketahui total pergerakan pada kawasan terkena dampak saat kondisi eksisting adalah sebesar 7.111 kend./hari. Dimana sebagian besar pergerakan berasal dari zona 5 yaitu arah Kabupaten Batang sebesar 1.905 kend./hari dan sebagian besar pergerakan menujuk ke zona 1 yaitu arah Kota Pekalongan sebesar 2.599 kend./hari.

Tabel 9. DistribusiPerjalananTahun 2018 (Konstruksi) (kend./hari) Sumber : Hasil Analisis

\begin{tabular}{|c|c|c|c|c|c|c|c|c|}
\hline & & \multirow[b]{2}{*}{ 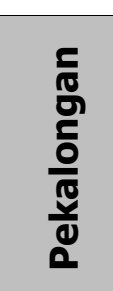 } & \multirow[b]{2}{*}{ 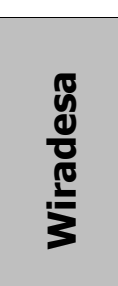 } & \multirow[b]{2}{*}{ 옹 } & \multirow[b]{2}{*}{ 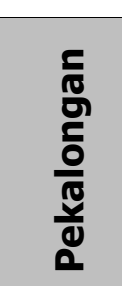 } & \multirow[b]{2}{*}{ 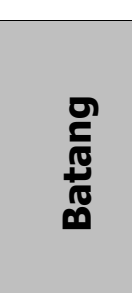 } & \multirow{2}{*}{\multicolumn{2}{|c|}{$\begin{array}{l}\text { Pada } \\
\text { taha } \\
\mathrm{p} \\
\text { kons } \\
\text { truks }\end{array}$}} \\
\hline & & & & & & & & \\
\hline & O/D & 1 & 2 & 3 & 4 & 5 & $\mathrm{Pj}$ & \\
\hline Pekalongan & 1 & 0 & 474 & 252 & 503 & 472 & 1701 & \\
\hline Wiradesa & 2 & 1020 & 0 & 112 & 200 & 304 & 1636 & \\
\hline Doro & 3 & 533 & 157 & 0 & 168 & 236 & 1094 & \\
\hline Pekalongan & 4 & 814 & 340 & 295 & 0 & 567 & 2016 & \\
\hline Batang & 5 & 817 & 529 & 198 & 690 & 0 & 2334 & \\
\hline & Aj & 3184 & 1500 & 957 & 1560 & 1579 & 8781 & \\
\hline
\end{tabular}

asan terkena dampak bertambah menjadi 8.781 kend./hari dari semula yang hanya sebesar 7.111 kend./hari. Sama halnya pada kondisi eksisting, asal pergerakan yang terjadi berasal dari zona 5 yaitu arah Kabupaten Batang sebesar 2.334 kend./hari. Dan sebagian besar pergerakan menuju ke zona 1 yaitu Kota Pekalongan sebesar 3.184 kend./hari, dengan asal pergerakan dari zona 2 sebesar 36\%, zona 5 sebesar 29\%, zona 4 sebesar $21 \%$ dan zona 3 sebesar $14 \%$. 
Tabel 10. DistribusiPerjalananTahun 2021 (Operasional) (kend./hari)

\begin{tabular}{|c|c|c|c|c|c|c|c|}
\hline & & 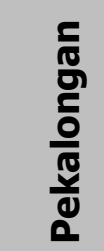 & $\begin{array}{l}\mathbb{8} \\
\frac{0}{0} \\
\frac{\pi}{5} \\
3\end{array}$ & 옴 & 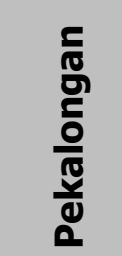 & $\begin{array}{l}\text { D } \\
\text { E } \\
\text { 芯 } \\
\text { D. }\end{array}$ & \\
\hline & O/D & 1 & 2 & 3 & 4 & 5 & $\mathrm{Pj}$ \\
\hline Pekalongan & 1 & 0 & 933 & 496 & 989 & 929 & 3347 \\
\hline Wiradesa & 2 & 2007 & 0 & 220 & 393 & 598 & 3218 \\
\hline Doro & 3 & 1049 & 308 & 0 & 331 & 464 & 2152 \\
\hline Pekalongan & 4 & 1601 & 669 & 581 & 0 & 1116 & 3966 \\
\hline Batang & 5 & 1607 & 1041 & 586 & 1357 & 0 & 4590 \\
\hline & $\mathrm{Aj}$ & 6264 & 2950 & 1883 & 3070 & 3107 & $\begin{array}{c}1727 \\
3\end{array}$ \\
\hline
\end{tabular}

Sumber : Hasil Analisis,

Pada saat Pasar Kedungwuni setahun beroperasi terjadi peningkatan pergerakan lebih dari dua kali lipat dibandingkan pada masa eksisting. Pada tahun 2021 ini pergerakan yang terjadi mencapai 17.273 kend./hari. Apabila dilihat dari asal pergerakannya, maka diketahui bahwa $27 \%$ berasal dari zona 5, 23\% dari zona 3, 19\% dari masing-masing zona 1 dan zona 2 serta $12 \%$ dari zona 3. Sedangkan bila dilihat dari tujuan pergerakannya, maka diketahui bahwa $36 \%$ dari zona $1,18 \%$ dari masing-masing zona 4 dan zona 5, 17\% dari zona 2 dan $11 \%$ dari zona 3.

Tahun 2031 saat Pasar Kedungwuni telah beroperasi 10 tahun lonjakan pergerakannya mencapai 33.979 kend./hari, dimana pergerakan tertinggi menuju zona 1 sebesar 12.322 kend./hari. Pada kondisi ini sudah tentu akan menyebabkan banyak masalah dan konflik lalulintas yang terjadi pada kawasan terdampak. Besarnya pergerakan yang terjadi akan sebanding pula dengan peningkatan volume lalulintas yang terjadi

Tabel 11. DistribusiPerjalananTahun 2031 (Operasional) (kend./hari)

\begin{tabular}{|c|c|c|c|c|c|c|c|}
\hline & & 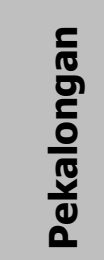 & $\begin{array}{l}\mathbb{8} \\
\frac{0}{0} \\
\frac{\pi}{5} \\
3\end{array}$ & 음 & 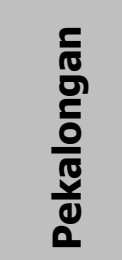 & 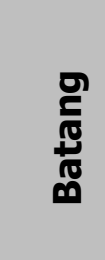 & \\
\hline & O/D & 1 & 2 & 3 & 4 & 5 & $\mathrm{Pj}$ \\
\hline Pekalongan & 1 & 0 & 1835 & 976 & 1945 & 1827 & 6583 \\
\hline Wiradesa & 2 & 3949 & 0 & 433 & 773 & 1176 & 6331 \\
\hline Doro & 3 & 2063 & 606 & 0 & 651 & 913 & 4233 \\
\hline Pekalongan & 4 & 3150 & 1315 & 1142 & 0 & 2195 & 7802 \\
\hline Batang & 5 & 3161 & 2048 & 1153 & 2669 & 0 & 9030 \\
\hline
\end{tabular}


Sumber : Hasil Analisis

\begin{tabular}{|c|c|c|c|c|c|c|}
$A j$ & 12322 & 5804 & 3704 & 6038 & 6112 & $\begin{array}{c}3397 \\
9\end{array}$ \\
\hline
\end{tabular}

\section{Analisis pemilihan moda}

Merupakan suatu tahapan dalam proses perencanaan transportasi. Analisis ini sangat penting untuk mengestimasikan jumlah kendaraan dimasa yang akan datang pada suatu jaringan jalan. Dari hasil analisis diperoleh prosentase pemilihan moda untuk melakukan pergerakan pada kawasan sekitar Pasar Kedungwuni sebagai berikut.

Tabel 12. PenggunaanModaTransportasi di Pasá Kedungwuni

\begin{tabular}{|l|c|}
\hline \multicolumn{1}{|c|}{ JenisModa } & Jumlah \\
\hline Sepeda Motor & 11.288 \\
\hline Mobil & 591 \\
\hline Truk/Box & 82 \\
\hline KendaraanTidakBermotor & 359 \\
\hline
\end{tabular}

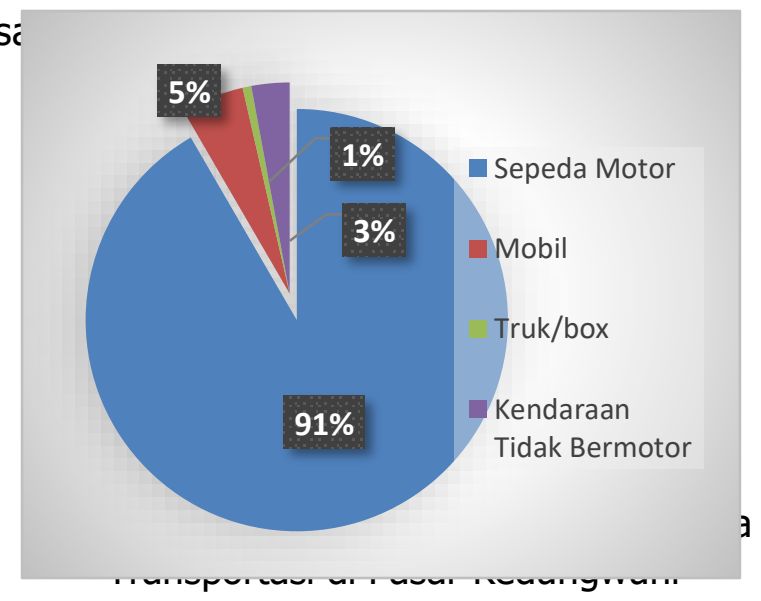

Dari data pada tabel dan grafikdiatasterlihatbahwapilihanmoda yang paling banyak di Pasar Kedungwuniadalahsepeda motor denganpersentasesebesar $91 \%$ atau 11.288 kendaraan.

\section{Kondisi Eksisting Kinerja Jaringan Jalan dan Simpang}

Data kinerja eksisting, Kinerja lalulintas pada jaringan jalan atau kinerja pada ruas jalan dan persimpangan untuk kondisi saat ini dapat dilihat sebagai berikut.

Tabel 13. KinerjaRuas Jalan Kondisi Eksisting

\begin{tabular}{|l|c|c|c|c|c|c|}
\hline \multicolumn{1}{|c|}{ Nama Ruas } & $\begin{array}{c}\text { Kapasit } \\
\text { as Jalan } \\
\mathbf{( s m p / j a} \\
\mathbf{m})\end{array}$ & $\begin{array}{c}\text { Volume } \\
\mathbf{( s m p / j a} \\
\mathbf{m})\end{array}$ & $\begin{array}{c}\text { V/C } \\
\text { Ratio }\end{array}$ & $\begin{array}{c}\text { Kecepata } \\
\mathbf{n} \\
\mathbf{( k m / j a m )}\end{array}$ & $\begin{array}{c}\text { Kepadata } \\
\mathbf{n} \\
\mathbf{( s m p / ~ k m ) ~}\end{array}$ & LoS \\
\hline Jalan Karanganyar - Podo & 2.513 & 1.304 & 0,52 & 43 & 30 & $\mathrm{C}$ \\
\hline Jalan Kedungwuni - Kutosari & 2.221 & 1.022 & 0,46 & 38 & 27 & $\mathrm{C}$ \\
\hline $\begin{array}{l}\text { Jalan Kedungwuni - } \\
\text { Karangdadap }\end{array}$ & 1.877 & 820 & 0,44 & 24 & 34 & $\mathrm{~B}$ \\
\hline
\end{tabular}

Kinerja Simpang ketig asimpang di kawasan studi terbagi menjadi dua jenis yaitu simpang bersinyal meliputi Simpang Podo dan simpang tak bersinyal meliputi Simpang 
Capgawen dan SimpangEks BCA. Untuk lebih jelasnya dapat dilihat pada table. 14 sebagai berikut.

Tabel 14. KinerjaSimpang Podo Kondisi Eksisting

Sumber : Hasil Analisis

\begin{tabular}{|c|c|c|c|c|c|}
\hline Pendekat & $\begin{array}{c}\text { Waktu } \\
\text { Siklus } \\
\text { (C) } \\
\text { (detik) }\end{array}$ & $\begin{array}{c}\text { Waktu } \\
\text { Hijau } \\
\text { (detik) }\end{array}$ & $\begin{array}{c}\text { Kapasita } \\
\text { S (C) } \\
\text { (detik) }\end{array}$ & $\begin{array}{l}\text { DerajatKe } \\
\text { jenuhan } \\
\text { (DS) }\end{array}$ & $\begin{array}{l}\text { TundaanL } \\
\text { apangan } \\
\text { (D) } \\
\text { (detik/sm } \\
\text { D) }\end{array}$ \\
\hline Utara (Jl. Raya Bebekan) & \multirow{3}{*}{63} & 25 & 1.900 & 0,63 & 8,11 \\
\hline $\begin{array}{l}\text { Selatan (Jl. Karanganyar - } \\
\text { Podo) }\end{array}$ & & 8 & 1.472 & 0,20 & 7,38 \\
\hline Barat (Jl. Raya Podo) & & 9 & 400 & 0,63 & 14,79 \\
\hline
\end{tabular}

Dimana diketahui bahwa kaki simpang Podo memiliki derajat kejenuhan 0,63 dalam kondisi eksisting simpang tiga Podo adalah simpang dengan pengendalian bersinyal dengan 3 fase.

Jalan Raya Bebekan

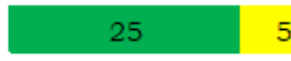

Jalan Karanganyar - Podo

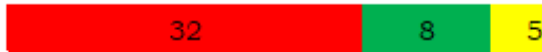

5

Jalan Raya Podo

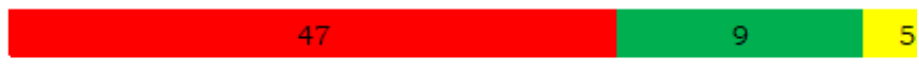

63 detik

Gambar 4. Diagram FaseSimpang Podo KondisiEksisting

Sedangkan kinerja simpang tak bersinyal yaitu Simpang Cap gawen dan Simpang Eks BCA diukur merujuk pada Indeks Tingkat Pelayanan (ITP) Lalu Lintas di Persimpangan oleh Tamin (2000), diketahui bahwa tingkat pelayanan kedua simpang tak bersinyal di kawasan studi memiliki tingkat pelayanan B karena memiliki tundaan per kendaraan kurang dari 15 detik. Untuk lebih jelasnya dapat dilihat pada table sebagai berikut.

Tabel 15. Kinerja Simpang Cap gawen dan Simpang Eks BCA Kondisi Eksisting

\begin{tabular}{|l|c|c|c|c|c|}
\hline Nama Simpang & $\begin{array}{c}\text { Volume } \\
\text { (smp/jam) }\end{array}$ & Kapasitas & $\begin{array}{c}\text { DerajatKe } \\
\text { jenuhan }\end{array}$ & $\begin{array}{c}\text { Tundaa } \\
\mathbf{n} \\
\text { (detik) }\end{array}$ & $\begin{array}{c}\text { Tingkat } \\
\text { Pelayana } \\
\mathbf{n}\end{array}$ \\
\hline SimpangCapgawen & 1.078 & 2.841 & 0,38 & 7,25 & $\mathrm{~B}$ \\
\hline SimpangEks BCA & 1.514 & 1.777 & 0,85 & 14,02 & $\mathrm{~B}$ \\
\hline
\end{tabular}


Beberapa trayek angkutan umum Kabupaten Pekalongan mempunyai rute yang melewati Pasar Kedungwuni, karena di lingkungan pasar tersebut juga terdapat terminal angkutan umum. Berdasarkan survey primer yang dilakukan, diketahui bahwa angkutan umum yang melewati Pasar Kedungwuni hanya melayani 1 rit/sekali jalan dan tidak kembali ke terminal dengan jumlah load factor rata-rata $31 \%$ yang artinya hanya terdapat $3-4$ penumpang pada angkutan dengan kapasitas 12 penumpang. Sedangkan frekuensi rataratanya 11 kend./jam dan headway 35 menit, yang artinya hanya terdapat 11 angkutan umum yang lewat dalam kurun waktu 1 jam dengan selang waktu antara angkutan umum satu dan lainnya adalah 35 menit. Dengan demikian dapat disimpulkan bahwa pelayanan angkutan umum yang melayani Pasar Kedungwuni belum optimal.

Tabel 16. Kondisi Pelayanan Angkutan Umum Rute Pasar Kedungwuni

\begin{tabular}{|l|c|c|c|}
\hline \multicolumn{1}{|c|}{ Waktu } & $\begin{array}{c}\text { Frekuensi } \\
\text { Rata-Rata } \\
\text { (kend./jam) }\end{array}$ & $\begin{array}{c}\text { Load Factor } \\
\text { Rata-Rata }\end{array}$ & $\begin{array}{c}\text { Headway } \\
\text { (menit) }\end{array}$ \\
\hline Weekday & 11 & $38 \%$ & 27 \\
\hline Weekend & 11 & $24 \%$ & 43 \\
\hline Rata-Rata & $\mathbf{1 1}$ & $\mathbf{3 1 \%}$ & $\mathbf{3 5}$ \\
\hline
\end{tabular}

Sumber : Hasil Analisis

\section{Simulasi Tahap Konstruksi}

Masa konstruksi pembangunan Pasar Kedungwuni ini direncanakan selama 3 tahun yakni dimulai daritahun 2018 sampai dengan tahun 2020. Prediksi dampak yang terjadi adalah terhadap kinerja ruas jalan dan persimpangan. Analisis yang digunakan yaitu menggunakan asumsi yang sama bahwa masa konstruksi dilakukan dalam 3 tahun rencana. Guna memprediksi volume lalulintas pada ruas dan persimpangan di masa yang akan datang, dapat dilakukan perhitungan dengan menggunakan metode factor pertumbuhan, yang memakaipersamaan :

\section{$\mathbf{P t}=$ Po. $(1+\mathbf{i})^{\mathbf{n}}+\mathbf{V b}+\mathbf{V t}$}

\section{Dimana :}

Pt = volume lalulintas pada tahunke-n

Po $\quad=$ volume lalulintas pada tahundasar

$\mathrm{i}=$ tingkatpertumbuhanlalulintas rata-rata

$\mathrm{n} \quad=$ selisihtahunantara Pt dan Po

$\mathrm{Vb} \quad=$ volume lalulintas yang dibangkitkan

$\mathrm{Vt} \quad=$ volume lalulintas yang ditarik

Lebih lanjut, dapat disampaikan pula bahwa dalam kurun waktu sampai dengan masa konstruksi telah terjadi peningkatan volume lalulintas yang disebabkan oleh pertumbuhan volume lalulintas. Berdasarkan data, rata-rata pertumbuhan lalulintas diasumsikan sebesar 7\% per tahun. Oleh karenanya, volume lalulintas tahun eksisting mengalami peningkatan menjadi $1.729 \mathrm{smp} / \mathrm{jam}$ di ruas Jalan Karanganyar - Podo, $1.383 \mathrm{smp} / \mathrm{jam}$ di ruas Jalan Kedungwuni - Kutosari dan $1.136 \mathrm{smp} / \mathrm{jam}$ di ruas Jalan Keudngwuni - Capgawen selama masa konstruksi. 


\section{Kinerja Ruas Jalan}

Dengan menggunakan indicator kinerja lalulintas yang sama yaitu $\mathrm{V} / \mathrm{C}$ ratio, tingkat pelayanan jalan dan kecepatan rata-rata, maka pada saat konstruksi menunjukkan penurunan kinerja lalulintas, ditunjukkan dengan nilai $\mathrm{V} / \mathrm{C}$ ratio yang semakin besar namun perubahannya tidak terlalu signifikan sehingga tingkat pelayanannya tidak mengalami perubahan kecuali pada ruas Jalan Kedungwuni - Karangdadap yang berubah pula menjadi $\mathrm{C}$ dengannilai $\mathrm{V} / \mathrm{C}$ ratio ruas Jalan Karanganyar - Podo 0,59, ruas Jalan Kedungwuni - Kutosari 0,53 dan ruas Jalan Kedungwuni - Karangdadap 0,52.

Sedangkan bila dilihat dari kecepatan, pada masa konstruksi nilainya cenderung menurun dibandingkan dengan tahun eksisting. Hal ini dikarenakan penambahan pembebanan dan penambahan volume lalulintas dengan factor pertumbuhan kendaraan yang ada. Untuk lebih jelasnya mengenai kinerja ruas jalan pada masa konstruksi dapat dilihat pada table berikut.

Tabel 17. KinerjaRuas Jalan TahapKonstruksi

\begin{tabular}{|c|c|c|c|c|c|c|}
\hline Nama Ruas & $\begin{array}{l}\text { Kapasitas } \\
\text { Jalan } \\
\text { (smp/jam } \\
\text { ) }\end{array}$ & $\begin{array}{c}\text { Volume } \\
(\mathrm{smp} / \mathrm{ja} \\
\mathrm{m})\end{array}$ & $\begin{array}{l}\text { V/C } \\
\text { Ratio }\end{array}$ & $\begin{array}{c}\text { Kecepata } \\
n \\
(\mathrm{~km} / \mathrm{jam} \\
)\end{array}$ & $\begin{array}{c}\text { Kepadata } \\
\text { n } \\
(\mathrm{smp} / \mathrm{km} \\
)\end{array}$ & LOS \\
\hline Jalan Raya Gembong & 2.513 & 1.479 & 0,59 & 37,8 & 39 & $\mathrm{C}$ \\
\hline $\begin{array}{l}\text { Jalan Raya } \\
\text { Kedungwuni }\end{array}$ & 2.221 & 1.187 & 0,53 & 32,7 & 36 & C \\
\hline Jalan Raya Capgawen & 1.877 & 978 & 0,52 & 20,1 & 49 & $\mathrm{C}$ \\
\hline $\begin{array}{l}\text { Jalan Raya Capgawen } \\
\text { (denganSistem Satu } \\
\text { Arah) }\end{array}$ & 2.340 & 878 & 0,38 & 24 & 37 & B \\
\hline
\end{tabular}

Sumber : Hasil Analisis

Pada tahap konstruksi ini, ruas Jalan Kedungwuni - Karangdadap yang merupakan akses utama Pasar Kedungwuni dilakukan simulasi system satu arah karena terlihat penurunan kinerja ditandai dengan $\mathrm{V} / \mathrm{C}$ ratio 0,52 yang termasuk dalam tingkat pelayanan $\mathrm{C}$. Ruas Jalan Kedungwuni - Karangdadap dengan lebar7,7 meter semula jalan dua arah dirubah menjadi satu arah dengan tujuan untuk meningkatkan kelancaran lalulintas selama masa konstruksi. Kapasitas jalan yang semula $1.877 \mathrm{smp} / \mathrm{jam}$ meningkat menjadi 2.340 $\mathrm{smp} / \mathrm{jam}$ dengan kecepatan $24 \mathrm{~km} / \mathrm{jam}$ dan kepadatan $37 \mathrm{smp} / \mathrm{km}$. Dengan V/C ratio 0,38 masih termasuk dalam tingkatpelayanan $\mathrm{B}$.

Sistem satu arah juga diberlakukan pada ruas jalan intern Pasar Kedungwuni saat tahap konstruksi. Hal ini untuk mengakomodir pengguna jalan yang dilarang menuju arah barat lewat Jalan Kedungwuni - Karangdadap. Adapun menurut indicator kinerja V/C ratio keempat jalan intern Pasar Kedungwuni masih dalam kategori $C$ kecuali Jalan Karangsari - Kedungwuni 1 yang masuk dalam kategori tingkat pelayanan $\mathrm{A}$ dengan $\mathrm{V} / \mathrm{C}$ ratio 0,19. Hal ini wajar terjadi karena dengan lebar jalan yang ada dan system satu arah di Jalan Kedungwuni - Karang dada pakan menyebabkan peningkatan V/C ratio ruas jalan di sekitar pasar. Untuk lebih jelasnya mengenai kinerja ruas jalan intern Pasar Kedungwuni pada masa konstruksi dapat dilihat pada table berikut. 


\section{Kinerja Simpang}

Selain berpengaruh terhadap kinerja jalan, tambahan bangkitan/tarikan pada tahap konstruksi akan mempengaruhi kinerja simpang di kawasan studi terkait dengan waktu tundaan. Simulasi kinerja simpang pada kawasan studi pada tahap konstruksi digambarkan pada tabelberikut.

Tabel18. Kinerja Simpang Podo Tahap Konstruksi

\begin{tabular}{|c|c|c|c|c|c|}
\hline Pendekat & $\begin{array}{c}\text { Waktu } \\
\text { Siklus } \\
\text { (C) } \\
\text { (detik) }\end{array}$ & $\begin{array}{c}\text { Waktu } \\
\text { Hijau } \\
\text { (detik) }\end{array}$ & $\begin{array}{c}\text { Kapasita } \\
\text { S (C) } \\
\text { (detik) }\end{array}$ & $\begin{array}{l}\text { DerajatKe } \\
\text { jenuhan } \\
\text { (DS) }\end{array}$ & $\begin{array}{c}\text { TundaanLa } \\
\text { pangan (D) } \\
\text { (detik/smp } \\
\text { ) }\end{array}$ \\
\hline Utara (Jl. Raya Bebekan) & \multirow{3}{*}{75} & 32 & 2.054 & 0,71 & 11,83 \\
\hline $\begin{array}{l}\text { Selatan (Jl. Raya Karanganyar - } \\
\text { Podo) }\end{array}$ & & 11 & 592 & 0,23 & 10,21 \\
\hline Barat (Jl. Raya Podo) & & 11 & 433 & 0,71 & 22,24 \\
\hline
\end{tabular}

Sumber : Hasil Analisis

Jalan Raya Bebekan

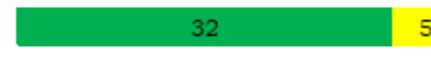

5

Jalan Karanganyar - Podo

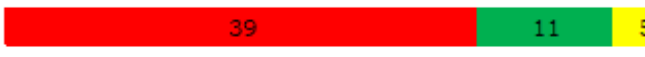

Jalan Raya Podo

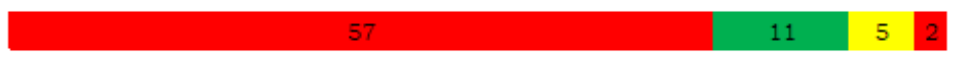

75 detik

Gambar 5. Diagram FaseSimpang Podo TahapKonstruksi

Berdasarkan diagram diatas dapat diketahui bahwa waktu siklus simpang pada tahap konstruksi mengalami perubahan yakni dari kondisi eksisting sebesar 63 detik menjadi 75 detik. Sedangkan kinerja kedua sinyal tak bersinyal lainnya diketahui mengalami perubahan juga, terutama Simpang Eks BCA dengan tundaan naik sampai dengan 27 detik, menyebabkan tingkat pelayanannya yang semula B berubah menjadi D. Untuk Simpang Capgawen tingkat pelayanannya tidak berubah yaitu B dengan tundaan 8,72 detik. Namun akibat simulasi system satua rah di Jalan Kedungwuni - Karangdadap pada masa konstruksi ternyata mempengaruhi tingkat pelayanan simpang terutama Simpang Eks BCA menjadi B dan Simpang Capgawen menjadi A. Untuk lebih jelasnya dapat dilihat pada table sebagai berikut.

Tabel 19. PerbandinganKinerjaSimpangCapgawen dan SimpangEks BCA

TahapKonstruksiTanpaPenangananDampak(Do-Nothing) dan DenganPenangananDampak(DoSomething)

\begin{tabular}{|c|c|c|c|c|c|c|}
\hline Forecasting & $\begin{array}{c}\text { Nama } \\
\text { Simpang }\end{array}$ & $\begin{array}{c}\text { Volume } \\
\text { (smp/jam } \\
\text { ) }\end{array}$ & $\begin{array}{c}\text { Kapasita } \\
\text { s }\end{array}$ & $\begin{array}{c}\text { DerajatKe } \\
\text { jenuhan }\end{array}$ & $\begin{array}{c}\text { Tundaa } \\
\mathbf{n} \\
\text { (detik) }\end{array}$ & $\begin{array}{c}\text { Tingkat } \\
\text { Pelayana } \\
\mathbf{n}\end{array}$ \\
\hline DO-NOTHING & SimpangCa & 1.452 & 2.841 & 0,51 & 8,72 & $\mathrm{~B}$ \\
\hline
\end{tabular}




\begin{tabular}{|c|c|c|c|c|c|c|}
\hline & pgawen & & & & & \\
\hline & $\begin{array}{l}\text { SimpangEk } \\
\text { s BCA }\end{array}$ & 1.986 & 1.777 & 1,12 & 27,00 & D \\
\hline \multirow{2}{*}{$\begin{array}{c}\text { DO-SOMETHING } \\
\text { (denganPerubaha } \\
\text { nSistem Satu } \\
\text { Arah pada Ruas } \\
\text { Jalan } \\
\text { Kedungwuni - } \\
\text { Karangdadap) }\end{array}$} & $\begin{array}{l}\text { SimpangCa } \\
\text { pgawen }\end{array}$ & 1.451 & 3.468 & 0,42 & 4,27 & A \\
\hline & $\begin{array}{l}\text { SimpangEk } \\
\text { s BCA }\end{array}$ & 1.495 & 2.234 & 0,67 & 6,97 & B \\
\hline
\end{tabular}

Sumber : Hasil Analisis,

\section{SIMULASI TAHAP OPERASIONAL}

Analisis tahapan operasional ini dilakukan simulasi pada tahun 2021 yaitu waktu operasional Pasar Kedungwuni setelah selesai tahap konstruksi dan 2031 yaitu sepuluh tahun mendatang saat Pasar Kedungwuni beroperasi.

\section{KinerjaRuas Jalan}

Berdasarkan hasil analisis sebelumnya terkait dengan $\mathrm{V} / \mathrm{C}$ ratio ruas jalan dari tahapan tahun rencana pengembangan maka diperlukan perubahan agar kinerja ruas jalan tidak mengalami penurunan kinerja yang signifikan. Manajemen dan rekayasa lalulintas serta manajemen kebutuhan yang diusulkan yaitu dengan meningkatkan kapasitas jalan. Dalam hal ini simulasi dengan melakukan pelebaran ruas Jalan Karanganyar - Podo, Jalan Kedungwuni - Kutosari dan Jalan Kedungwuni - Karangdadap menjadi 12 meter dengan median.

Perhitungan volume lalulintas pada tahap ini digunakan formulasi yang sama, yaitu menghitung volume lalulintas berdasarkan factor pertumbuhan rata-rata sebesar $7 \%$ per tahun, besaran lalulintas pada tahun operasional 2021 adalah 2.777 smp/jam untuk Jalan Karanganyar - Podo, $2.335 \mathrm{smp} / \mathrm{jam}$ untuk Jalan Kedungwuni - Kutosari dan 1.925 smp/jam untuk Jalan Kedungwuni - Karangdadap. Secara rinci kinerja ruasjalanterdampakdapatdilihat pada tabelberikut.

Tabel 20. KapasitasRuas Jalan Diusulkan 


\begin{tabular}{|c|c|c|c|c|}
\hline Nama Ruas & Tipe & Fungs & $\begin{array}{l}\text { Kapasitas } \\
\text { (smp/jam) }\end{array}$ & $\begin{array}{c}\text { Lebar } \\
\text { Jalan } \\
\text { (m) }\end{array}$ \\
\hline Jl. Karanganyar - Podo (Arah Selatan) & \multirow{6}{*}{$4 / 2 \mathrm{D}$} & \multirow{6}{*}{ Primer } & 4.794 & \multirow{6}{*}{12} \\
\hline Jl. Karanganyar - Podo (Arah Utara) & & & 4.794 & \\
\hline Jl. Kedungwuni - Kutosari (Arah Selatan) & & & 4.794 & \\
\hline Jl. Kedungwuni - Kutosari (Arah Utara) & & & 4.794 & \\
\hline $\begin{array}{l}\text { Jl. Kedungwuni - Karangdadap (Arah } \\
\text { Barat) }\end{array}$ & & & 4.452 & \\
\hline $\begin{array}{l}\text { Jl. Kedungwuni - Karangdadap (Arah } \\
\text { Timur) }\end{array}$ & & & 4.452 & \\
\hline
\end{tabular}

Sumber : Hasil Analisis

Tabel 21. PerbandinganKinerjaRuas Jalan Karanganyar - Podo

BerbagaiTahapanTanpaPenangananDampak(Do-Nothing) dan DenganPenangananDampak(DoSomething)

\begin{tabular}{|c|c|c|c|c|c|c|c|c|}
\hline Forecasting & Tahun & Arah & 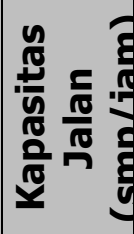 & 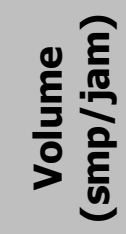 & $\begin{array}{l}\frac{0}{2} \\
\frac{10}{\alpha} \\
\frac{u}{3}\end{array}$ & 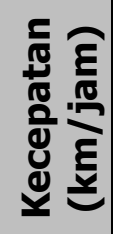 & 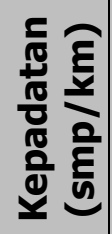 & LOS \\
\hline \multirow{4}{*}{$\begin{array}{c}\text { DO - } \\
\text { NOTHING }\end{array}$} & 2018 (Eksisting) & - & 2.513 & 1.304 & $\begin{array}{c}0,5 \\
2\end{array}$ & 43 & 30 & $\mathrm{C}$ \\
\hline & 2018 (Konstruksi) & - & 2.513 & 1.479 & $\begin{array}{c}0,5 \\
9\end{array}$ & 37,8 & 39 & $\mathrm{C}$ \\
\hline & $\begin{array}{c}2021 \\
\text { (Operasional) }\end{array}$ & - & 2.513 & 2.777 & $\begin{array}{c}1,1 \\
1\end{array}$ & 20,1 & 138 & $F$ \\
\hline & $\begin{array}{c}2031 \\
\text { (Operasional) }\end{array}$ & - & 2.513 & 5.464 & $\begin{array}{c}2,1 \\
7\end{array}$ & 10,2 & 534 & $F$ \\
\hline \multirow{4}{*}{$\begin{array}{c}\text { DO - } \\
\text { SOMETHIN } \\
G\end{array}$} & \multirow{2}{*}{$\begin{array}{c}2021 \\
\text { (Operasionaldeng } \\
\text { anPerubahanKap } \\
\text { asitas) }\end{array}$} & Selatan & 4.794 & 1.743 & $\begin{array}{c}0,3 \\
6\end{array}$ & 61,2 & 28 & B \\
\hline & & Utara & 4.794 & 1.757 & $\begin{array}{c}0,3 \\
7\end{array}$ & 60,7 & 29 & B \\
\hline & \multirow{2}{*}{$\begin{array}{c}2031 \\
\text { (Operasionaldeng } \\
\text { anPerubahanKap } \\
\text { asitas) }\end{array}$} & Selatan & 4.909 & 3.429 & $\begin{array}{c}0,7 \\
0\end{array}$ & 31,9 & 108 & $\mathrm{C}$ \\
\hline & & Utara & 4.909 & 3.456 & $\begin{array}{c}0,7 \\
0\end{array}$ & 31,6 & 109 & $\mathrm{C}$ \\
\hline
\end{tabular}

Berdasarkan table diatas diketahui bahwa ruas Jalan Karanganyar - Podo dengan lebar jalan10 meter mempunyai kapasitas $2.513 \mathrm{smp} / \mathrm{jam}$. Jika volume lalulintas pada tahun operasional 2021 sebesar 2.777 smp/jam maka V/C rationya 1,11 dan termasuk dalam kategori tingkat pelayanan F. Sehingga pada tahun yang sama dilakukan penanganan berupa pelebaran jalan menjadi 12 meter dengan median sehingga kapasitasnya meningkat menjadi $4.794 \mathrm{smp} / \mathrm{jam}$ untuk masing-masing arah selatan dan utara. 
Dengan volume $1.743 \mathrm{smp} / \mathrm{jam}$ dan $\mathrm{V} / \mathrm{C}$ ratio 0,36 untuk arah selatan serta volume $1.757 \mathrm{smp} / \mathrm{jam}$ dan $\mathrm{V} / \mathrm{C}$ ratio 0,37 untuk arah utara, tingkat pelayanannya berubah menjadi B. Namun saat volume lalulintas semakin meningkat pada tahun 2031, dengan peningkatan kapasitas menjadi $4.909 \mathrm{smp} / \mathrm{jam}$ untuk masing-masing arah selatan dan utara. Dengan volume $3.429 \mathrm{smp} / \mathrm{jam}$ untuk arah selatan dan $3.456 \mathrm{smp} / \mathrm{jam}$ untuk arah utara dengan $\mathrm{V} / \mathrm{C}$ ratio 0,70 tingkat pelayanannya berubah menjadi $\mathrm{C}$.

Tabel 22. Perbandingan Kinerja Ruas Jalan Kedungwuni - Kutosari Berbagai Tahapan Tanpa Penanganan Dampak(Do-Nothing) dan Dengan Penanganan Dampak(Do-Something)

\begin{tabular}{|c|c|c|c|c|c|c|c|c|}
\hline Forecasting & Tahun & Arah & 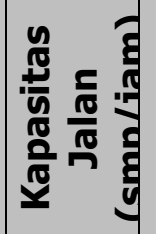 & 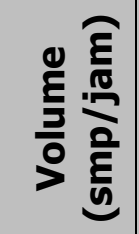 & 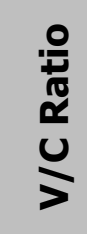 & 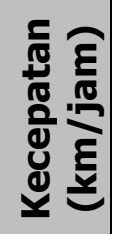 & 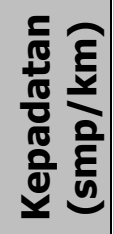 & LOS \\
\hline \multirow{4}{*}{$\begin{array}{c}\text { DO- } \\
\text { NOTHING }\end{array}$} & 2018 (Eksisting) & - & 2.221 & 1.022 & $\begin{array}{c}0,4 \\
6\end{array}$ & 38 & 27 & C \\
\hline & 2018 (Konstruksi) & - & 2.221 & 1.187 & $\begin{array}{c}0,5 \\
3\end{array}$ & 32,7 & 36 & C \\
\hline & $\begin{array}{c}2021 \\
\text { (Operasional) }\end{array}$ & - & 2.221 & 2.335 & $\begin{array}{c}1,0 \\
5\end{array}$ & 16,6 & 140 & $\mathrm{~F}$ \\
\hline & $\begin{array}{c}2031 \\
\text { (Operasional) }\end{array}$ & - & 2.221 & 5.464 & $\begin{array}{c}2,4 \\
6\end{array}$ & 7,1 & 769 & $\mathrm{~F}$ \\
\hline \multirow{4}{*}{$\begin{array}{c}\text { DO - } \\
\text { SOMETHIN } \\
G\end{array}$} & \multirow{2}{*}{$\begin{array}{c}2021 \\
\text { (Operasionaldeng } \\
\text { anPerubahanKap } \\
\text { asitas) }\end{array}$} & Selatan & 4.794 & 1.522 & $\begin{array}{c}0,3 \\
2\end{array}$ & 55,1 & 28 & B \\
\hline & & Utara & 4.794 & 1.194 & $\begin{array}{c}0,2 \\
5\end{array}$ & 70,2 & 17 & B \\
\hline & \multirow{2}{*}{$\begin{array}{c}2031 \\
\begin{array}{c}\text { (Operasionaldeng } \\
\text { anPerubahanKap } \\
\text { asitas) }\end{array} \\
\end{array}$} & Selatan & 4.909 & 2.994 & $\begin{array}{c}0,6 \\
1\end{array}$ & 28,7 & 104 & C \\
\hline & & Utara & 4.909 & 2.349 & $\begin{array}{c}0,4 \\
8\end{array}$ & 36,5 & 64 & C \\
\hline
\end{tabular}

Berdasarkan table diatas diketahui bahwa ruas Jalan Kedungwuni - Kutosari mempunyai kapasitas $2.221 \mathrm{smp} / \mathrm{jam}$. Jika volume lalulintas pada tahun operasional 2021 sebesar $5.464 \mathrm{smp} / \mathrm{jam}$ maka $\mathrm{V} / \mathrm{C}$ rationya 2,46 dan termasuk dalam kategori tingkat pelayanan F. Pada tahun yang sama dilakukan penanganan berupa pelebaran jalan menjadi 12 meter dengan median sehingga kapasitasnya meningkat menjadi $4.794 \mathrm{smp} / j a m$ untuk masing-masing arah selatan dan utara. Jalan Kedungwuni - Kutosari arah selatan mempunyai volume $1.522 \mathrm{smp} / \mathrm{jam}$ dan V/C ratio 0,32 dan arah utara mempunyai volume $1.194 \mathrm{smp} / \mathrm{jam}$ dan V/C ratio 0,25, sehingga Jalan Raya Kedungwuni baik arah selatan dan utara termasuk dalam tingkat pelayanan B. Namun saat volume lalulintas semakin meningkat pada tahun 2031, dengan peningkatan kapasitas menjadi 4.909 $\mathrm{smp} / \mathrm{jam}$ untuk masing-masing arah selatan dan utara. Dengan volume $2.994 \mathrm{smp} / \mathrm{jam}$ 
dan $\mathrm{V} / \mathrm{C}$ ratio 0,61 untuk arah selatan dan dengan volume $2.349 \mathrm{smp} / \mathrm{jam}$ dan $\mathrm{V} / \mathrm{C}$ ratio 0,48 untuk arah utara tingkat pelayanannya berubah menjadi $\mathrm{C}$.

Sedangkan ruas Jalan Kedungwuni - Karangdadap dengan lebar eksisting7,7 metermempunyai kapasitas $1.877 \mathrm{smp} / \mathrm{jam}$. Jika volume lalulintas pada tahun operasional 2021 sebesar $1.925 \mathrm{smp} / \mathrm{jam}$ maka V/C rationya 1,03 dan termasuk dalam kategori tingkat pelayanan F. Pada tahun yang sama dilakukan penanganan berupa pelebaran jalan menjadi 12 meter dengan median sehingga kapasitasnya meningkat menjadi $4.452 \mathrm{smp} / \mathrm{jam}$ untuk masing-masing arah barat dan timur. Jalan Kedungwuni Karangdadap arah barat mempunyai volume $781 \mathrm{smp} / \mathrm{jam}$ dan $\mathrm{V} / \mathrm{C}$ ratio 0,18 termasuk dalam tingkat pelayanan A serta arah timur mempunyai volume $1.065 \mathrm{smp} / \mathrm{jam}$ dan $\mathrm{V} / \mathrm{C}$ ratio 0,24 termasuk dalam tingkat pelayanan B. Namun diketahui juga bahwa saat volume lalulintas semakin meningkat pada tahun 2031, penambahan kapasitas menjadi $4.452 \mathrm{smp} / \mathrm{jam}$ dan volume lalulintas untuk arah barat $1.536 \mathrm{smp} / \mathrm{jam}$ dan arah timur $2.095 \mathrm{smp} / \mathrm{jam}$ merubah tingkat pelayanan yaitu $\mathrm{B}$ dengan $\mathrm{V} / \mathrm{C}$ ratio 0,35 untuk arah barat dan $\mathrm{C}$ dengan $\mathrm{V} / \mathrm{C}$ ratio 0,47 untuk arah timur.

Tabel 23. Perbandingan Kinerja Ruas Jalan Kedungwuni - Karangdadap Berbagai Tahapan

Tanpa Penanganan Dampak (Do-Nothing) dan Dengan Penanganan Dampak (Do-Something)

\begin{tabular}{|c|c|c|c|c|c|c|c|c|}
\hline Forecasting & Tahun & Arah & 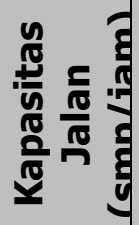 & 突 & 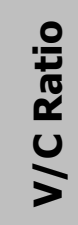 & 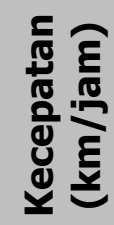 & 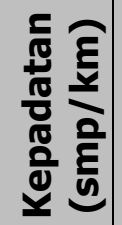 & LOS \\
\hline \multirow{4}{*}{$\begin{array}{c}\text { DO- } \\
\text { NOTHING }\end{array}$} & 2018 (Eksisting) & - & 1.877 & 820 & $\begin{array}{c}0,4 \\
4\end{array}$ & 24 & 34 & B \\
\hline & 2018 (Konstruksi) & - & 1.877 & 978 & $\begin{array}{c}0,5 \\
2 \\
\end{array}$ & 20,1 & 49 & C \\
\hline & 2021 (Operasional) & - & 1.877 & $\begin{array}{l}1.92 \\
5\end{array}$ & $\begin{array}{c}1,0 \\
3\end{array}$ & 10,2 & 188 & $\mathrm{~F}$ \\
\hline & 2031 (Operasional) & $\begin{array}{l}- \\
-\end{array}$ & 1.877 & $\begin{array}{c}4.59 \\
4\end{array}$ & $\begin{array}{c}2,4 \\
5\end{array}$ & 4,3 & $\begin{array}{c}1.07 \\
2\end{array}$ & $\mathrm{~F}$ \\
\hline \multirow{5}{*}{$\begin{array}{c}\text { DO - } \\
\text { SOMETHIN } \\
G\end{array}$} & $\begin{array}{c}2018 \\
\text { (KonstruksidenganS } \\
\text { istem Satu Arah) }\end{array}$ & - & 2.340 & 878 & $\begin{array}{c}0,3 \\
8\end{array}$ & 24 & 37 & B \\
\hline & \multirow{2}{*}{$\begin{array}{c}2021 \\
\text { (Operasionaldenga } \\
\text { nPerubahanKapasit } \\
\text { as) }\end{array}$} & Barat & 4.452 & 781 & $\begin{array}{c}0,1 \\
8\end{array}$ & 59,8 & 13 & A \\
\hline & & Timur & 4.452 & $\begin{array}{l}1.06 \\
5\end{array}$ & $\begin{array}{c}0,2 \\
4\end{array}$ & 43,8 & 24 & B \\
\hline & \multirow{2}{*}{$\begin{array}{c}2031 \\
\text { (Operasionaldenga } \\
\text { nPerubahanKapasit } \\
\text { as) }\end{array}$} & Barat & 4.452 & $\begin{array}{c}1.53 \\
6\end{array}$ & $\begin{array}{c}0,3 \\
5\end{array}$ & 30,4 & 51 & $B$ \\
\hline & & Timur & 4.452 & $\begin{array}{c}2.09 \\
5\end{array}$ & $\begin{array}{c}0,4 \\
7\end{array}$ & 22,3 & 94 & C \\
\hline
\end{tabular}




\section{Simpang Podo}

Tambahan volume kendaraan berdasarkan factor pertumbuhan rata-rata $7 \%$ per tahun tentu saja akan berpengaruh pada kinerja simpang di kawasan studi. Secara umum pada masa operasional tahun 2021 dan tahun 2031 terjadi penurunan kinerja simpang di kawasan studi. Adapun lebih jelasnya dapat dilihat pada table sebagai berikut.

Sumber : Hasil Analisis

Tabel 24. KinerjaSimpang Podo Tahap Operasional

\begin{tabular}{|c|c|c|c|c|c|}
\hline Pendekat & $\begin{array}{l}\text { Waktu } \\
\text { Siklus } \\
\text { (C) } \\
\text { (detik) }\end{array}$ & $\begin{array}{c}\text { Wakt } \\
\text { u } \\
\text { Hijau } \\
\text { (detik } \\
\text { ) }\end{array}$ & $\begin{array}{c}\text { Kapasita } \\
\text { S (C) } \\
\text { (detik) }\end{array}$ & $\begin{array}{l}\text { DerajatK } \\
\text { ejenuhan } \\
\text { (DS) }\end{array}$ & $\begin{array}{c}\text { TundaanLa } \\
\text { pangan (D) } \\
\text { (detik/smp } \\
\text { ) }\end{array}$ \\
\hline \multicolumn{6}{|c|}{ Tahun 2021 (Operasionaldengan 3 fase) } \\
\hline Utara (Jl. Raya Bebekan) & \multirow{3}{*}{165} & 89 & 3.231 & 0,89 & 36,42 \\
\hline $\begin{array}{l}\text { Selatan (Jl. Karanganyar - } \\
\text { Podo) }\end{array}$ & & 27 & 2.671 & 0,27 & 30,83 \\
\hline Barat (Jl. Raya Podo) & & 28 & 681 & 0,89 & 67,12 \\
\hline \multicolumn{6}{|c|}{ Tahun 2021 (Operasionaldengan 2 fase) } \\
\hline Utara (Jl. Raya Bebekan) & \multirow{3}{*}{71} & \multirow[b]{2}{*}{43} & 3.657 & 0,79 & 13,08 \\
\hline $\begin{array}{l}\text { Selatan (Jl. Karanganyar - } \\
\text { Podo) }\end{array}$ & & & 3.023 & 0,24 & 19,80 \\
\hline Barat (Jl. Raya Podo) & & 14 & 770 & 0,79 & 28,23 \\
\hline \multicolumn{6}{|l|}{ Tahun 2031 (Operasional) } \\
\hline Utara (Jl. Raya Bebekan) & \multirow{3}{*}{-189} & \multirow[b]{2}{*}{-160} & 5.033 & 1,06 & 724,31 \\
\hline $\begin{array}{l}\text { Selatan (Jl. Karanganyar - } \\
\text { Podo) }\end{array}$ & & & 4.213 & 0,34 & $-81,33$ \\
\hline Barat (Jl. Raya Podo) & & -43 & 1.128 & 1,06 & 231,71 \\
\hline
\end{tabular}

Jalan Raya Bebekan

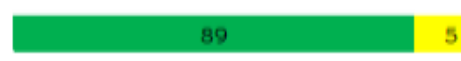

5

Jalan Karanganyar - Podo

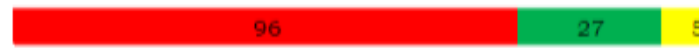

5

Jalan Raya Podo

165 detik

Gambar 6. Diagram FaseSimpang Podo Tahun 2021

(Operasionaldengan 3 Fase) 
Utara - Selatan

Barat
43

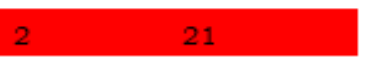

Gambar 7. Diagram FaseSimpang Podo Tahun 2021

(Operasionaldengan 2 Fase)

Pada tahun operasional 2021, pada Simpang Podo dilakukan simulasi kinerja simpang dengan 3 fase dan 2 fase. Hal ini terjadi karena waktu siklus simpang pada tahun 2021 mengalami perubahan yang signifikan setelah adanya pembangunan Pasar Kedungwuni yakni dari kondisi eksisting 63 detik, pada tahun 2021 dengan 3 fase sebesar 165 detik. Oleh karena itu sebagai upaya antisipasi maka diusulkan pada tahun 2021 merubah Simpang Podo dengan 2 fase untuk mengurangi derajat kejenuhan dan tundaannya.

Tabel 25. Perbandingan Kinerja Simpang Podo

\begin{tabular}{|l|c|c|c|c|c|c|}
\hline \multirow{2}{*}{ Tahun } & \multicolumn{3}{|c|}{ DerajatKejenuhan } & \multicolumn{3}{c|}{ Tundaan } \\
\cline { 2 - 7 } & Utara & Selatan & Barat & Utara & Selatan & Barat \\
\hline 2018 (Eksisting) & 0,63 & 0,20 & 0,63 & 8,11 & 7,38 & 14,79 \\
\hline 2018 (Konstruksi) & 0,71 & 0,23 & 0,71 & 11,83 & 10,21 & 22,24 \\
\hline $\begin{array}{l}\text { 2021 (Operasionaldgn 3 } \\
\text { Fase) }\end{array}$ & 0,89 & 0,27 & 0,89 & 36,83 & 30,83 & 67,12 \\
\hline $\begin{array}{l}\text { 2021 (Operasionaldgn 2 } \\
\text { Fase) }\end{array}$ & 0,79 & 0,24 & 0,79 & 13,08 & 19,80 & 28,23 \\
\hline 2031 (Operasional) & 1,06 & 0,34 & 1,06 & 724,31 & $-81,33$ & 231,71 \\
\hline
\end{tabular}




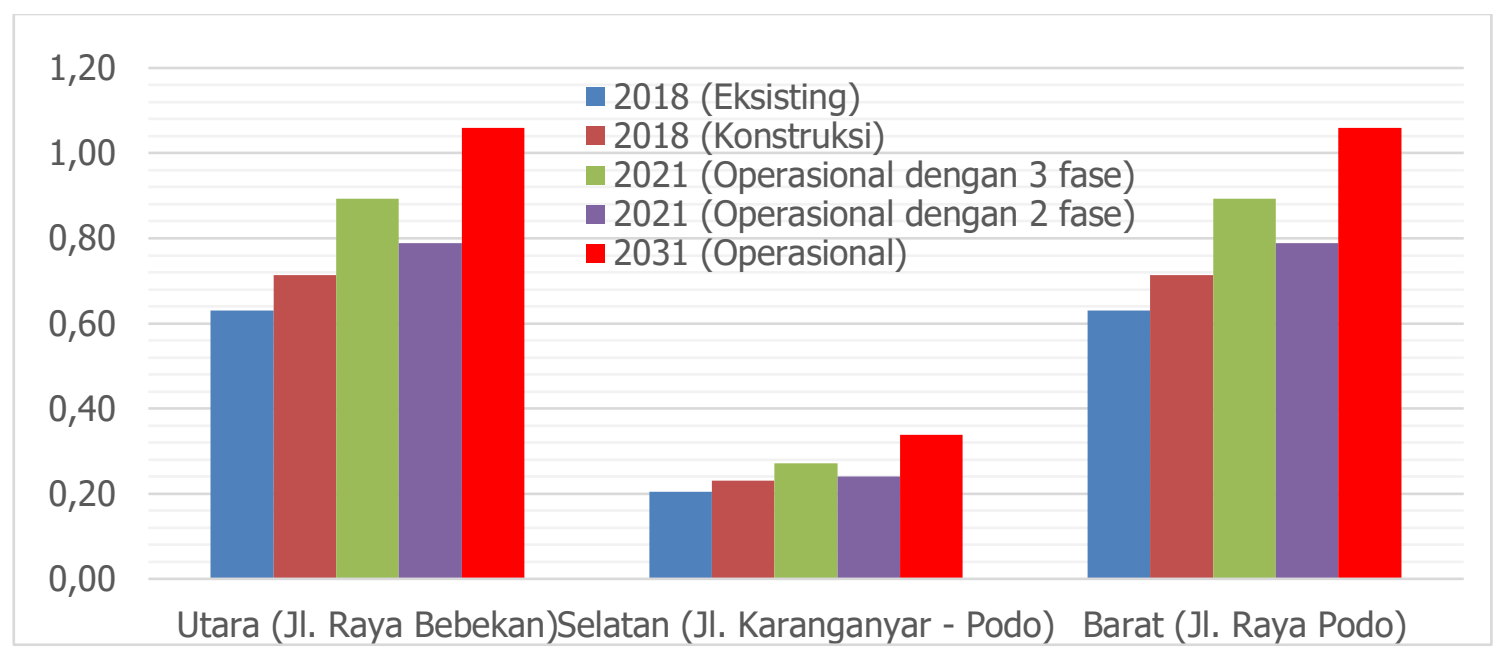

Gambar 8. Perbandingan Kinerja Derajat Kejenuhan Simpang Podo

Apabila dilihat berdasarkan jenis pengendalian simpangnya, Simpang Podo termasuk dalam jenis pengendalian bundaran atau APILL. Hal ini diperoleh dari jumlah volume jalan mayor dan minornya yang kemudian dibandingkan sesuai grafik pengendalian simpang. Dengan volume jalan mayor 15.477 kend./hari dan volume jalan minor 8.576 kend./hari maka berdasarkan grafik Simpang Podo termasuk dalam jenis pengendalian Bundaran dan APILL.

Tabel 26.Jenis PengendalianS impang Podo

\begin{tabular}{|l|c|c|c|}
\hline \multirow{2}{*}{ Nama Simpang } & \multicolumn{2}{|c|}{ Jumlah Volume } & \multirow{2}{*}{ JenisPengendalian } \\
\cline { 2 - 3 } & Mayor & Minor & \\
\hline Simpang Podo & 15.477 & 8.576 & \multirow{2}{*}{ Bundaranatau APILL } \\
\hline
\end{tabular}

Sumber : Hasil Analisis

Secara rinci mengenai lebar pendekat pada Simpang Podo dapat dilihat pada table berikut.

Tabel 27. Perbandingan Lebar Pendekat Simpang Podo Berbagai Tahapan

\begin{tabular}{|l|c|c|c|}
\hline \multirow{2}{*}{\multicolumn{1}{|c|}{ Tahun }} & \multicolumn{3}{|c|}{ LebarPendekat (m) } \\
\cline { 2 - 4 } & Utara & Selatan & Barat \\
\hline 2018 (Eksisting) & 10 & 9,5 & 8 \\
\hline 2018 (Konstruksi) & 10 & 9,5 & 8 \\
\hline 2021 (Operasional) & 12 & 12 & 10 \\
\hline 2031 (Operasional) & 12 & 12 & 12 \\
\hline
\end{tabular}

Sumber : Hasil Analisis

\section{Simpang Eks Bca}


Seperti halnya Simpang Podo yang telah dibahas sebelumnya, di Simpang Eks BCA juga terjadi penurunan kinerja simpang. Berdasarkan hasil analisis diketahui bahwa tingkat pelayanan Simpang Eks BCA pada kondisi eksisting adalah B, namun kondisi ini menurun pada tahap konstruksi dimana tingkat pelayanannya menjadi $D$ dengan tundaan 27 detik. Oleh karenaitu pada tahap operasional tahun 2021 dan tahun 2031 ini diusulkan untuk memasang APILL pada Simpang Eks BCA ini sebagai bentuk pengendalian konflik lalulintas pada simpang ini. Adapun lebih jelasnya dapat dilihat pada table sebagai berikut.

Tabel 28. KinerjaSimpangEks BCA TahapOperasional

\begin{tabular}{|c|c|c|c|c|c|}
\hline Pendekat & $\begin{array}{c}\text { Waktu } \\
\text { Siklus } \\
\text { (C) } \\
\text { (detik) }\end{array}$ & $\begin{array}{c}\text { Wakt } \\
\text { u } \\
\text { Hijau } \\
\text { (detik }\end{array}$ & $\begin{array}{c}\text { Kapasita } \\
\text { s (C) } \\
\text { (detik) }\end{array}$ & $\begin{array}{c}\text { DerajatKe } \\
\text { jenuhan } \\
\text { (DS) }\end{array}$ & $\begin{array}{c}\text { TundaanLa } \\
\text { pangan (D) } \\
\text { (detik/smp } \\
\text { ) }\end{array}$ \\
\hline \multicolumn{6}{|c|}{ Tahun 2021 (Operasionaldengan 3 fase) } \\
\hline Selatan (Jl. Kedungwuni - Kutosari) & \multirow{3}{*}{71} & 19 & 1.522 & 0,69 & 10,28 \\
\hline Utara (Jl. Karanganyar - Podo) & & 16 & 1.356 & 0,59 & 8,05 \\
\hline $\begin{array}{l}\text { Timur (Jl. Kedungwuni - } \\
\text { Karangdadap) }\end{array}$ & & 15 & 1.231 & 0,69 & 11,45 \\
\hline \multicolumn{6}{|c|}{ Tahun 2031 (Operasionaldengan 3 fase) } \\
\hline Selatan (Jl. Kedungwuni - Kutosari) & \multirow{3}{*}{324} & 117 & 2.183 & 0,95 & 79,86 \\
\hline Utara (Jl. Karanganyar - Podo) & & 99 & 1.946 & 0,81 & 46,47 \\
\hline $\begin{array}{l}\text { Timur (Jl. Kedungwuni - } \\
\text { Karangdadap) }\end{array}$ & & 87 & 1.765 & 0,95 & 87,23 \\
\hline \multicolumn{6}{|c|}{ Tahun 2031 (Operasionaldengan 2 fase) } \\
\hline Selatan (Jl. Kedungwuni - Kutosari) & \multirow{3}{*}{72} & \multirow{2}{*}{33} & 2.615 & 0,79 & 15,09 \\
\hline Utara (Jl. Karanganyar - Podo) & & & 2.330 & 0,67 & 19,43 \\
\hline $\begin{array}{l}\text { Timur (Jl. Kedungwuni - } \\
\text { Karangdadap) }\end{array}$ & & 25 & 2.115 & 0,79 & 17,71 \\
\hline
\end{tabular}

Gambar 9. Diagram Fase Simpang Eks BCA Tahun 2021

(Operasional dengan 3 Fase) 
Jalan Kedungwuni - Kutosari

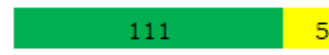

Jalan Karanganyar - Podo

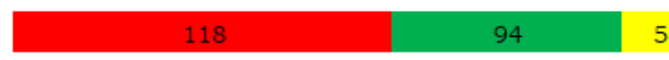

Jalan Kedungwuni - Karangdadap

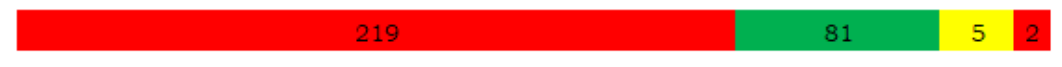

307 detik

Gambar 10. Diagram Fase Simpang Eks BCA Tahun 2031

(Operasional dengan 3 Fase)

Utara - Selatan

Timur

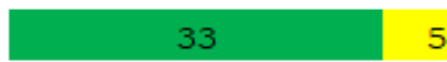

5

71 detik

Gambar 11. Diagram Fase Simpang Eks BCA Tahun 2031

(Operasional dengan 2 Fase)

Pada tahun operasional 2021 dan 2031 pada Simpang Eks BCA dilakukan simulasi kinerja simpang dengan 3 fase. Namun pada tahun 2031 saat Pasar Kedungwuni beroperasi selama 10 tahun, waktu siklus Simpang Eks BCA mengalami perubahan yang signifikan yakni dari 70 detik pada tahun 2021 menjadi 307 detik pada tahun 2031. Oleh karena itu sebagai upaya antisipasi maka diusulkan pada tahun 2031 merubah Simpang Eks BCA dengan 2 fase untuk mengurangi derajat kejenuhan dan tundaannya.

Tabel 29. Perbandingan Kinerja Simpang Eks BCA

\begin{tabular}{|l|c|c|c|c|c|c|}
\hline \multirow{2}{*}{ Tahun } & \multicolumn{4}{|c|}{ DerajatKejenuhan } & \multicolumn{3}{c|}{ Tundaan } \\
\cline { 2 - 7 } & Selatan & Utara & Timur & Selatan & Utara & Timur \\
\hline 2018 (Eksisting) & 0,73 & 0,53 & 0,73 & 14,61 & 8,23 & 15,54 \\
\hline $\begin{array}{l}2021 \\
\text { (Operasionaldgn } \\
\text { 3 Fase) }\end{array}$ & 0,69 & 0,59 & 0,69 & 10,28 & 8,05 & 11,45 \\
\hline $\begin{array}{l}2031 \\
\text { (Operasionaldgn } \\
\text { 3 Fase) }\end{array}$ & 0,95 & 0,81 & 0,95 & 79,86 & 46,47 & 87,23 \\
\hline $\begin{array}{l}\text { 2031 } \\
\text { (Operasionaldgn }\end{array}$ & 0,79 & 0,67 & 0,79 & 15,09 & 19,43 & 17,71 \\
\hline
\end{tabular}




\section{Fase)}

Sumber : Hasil Analisis,

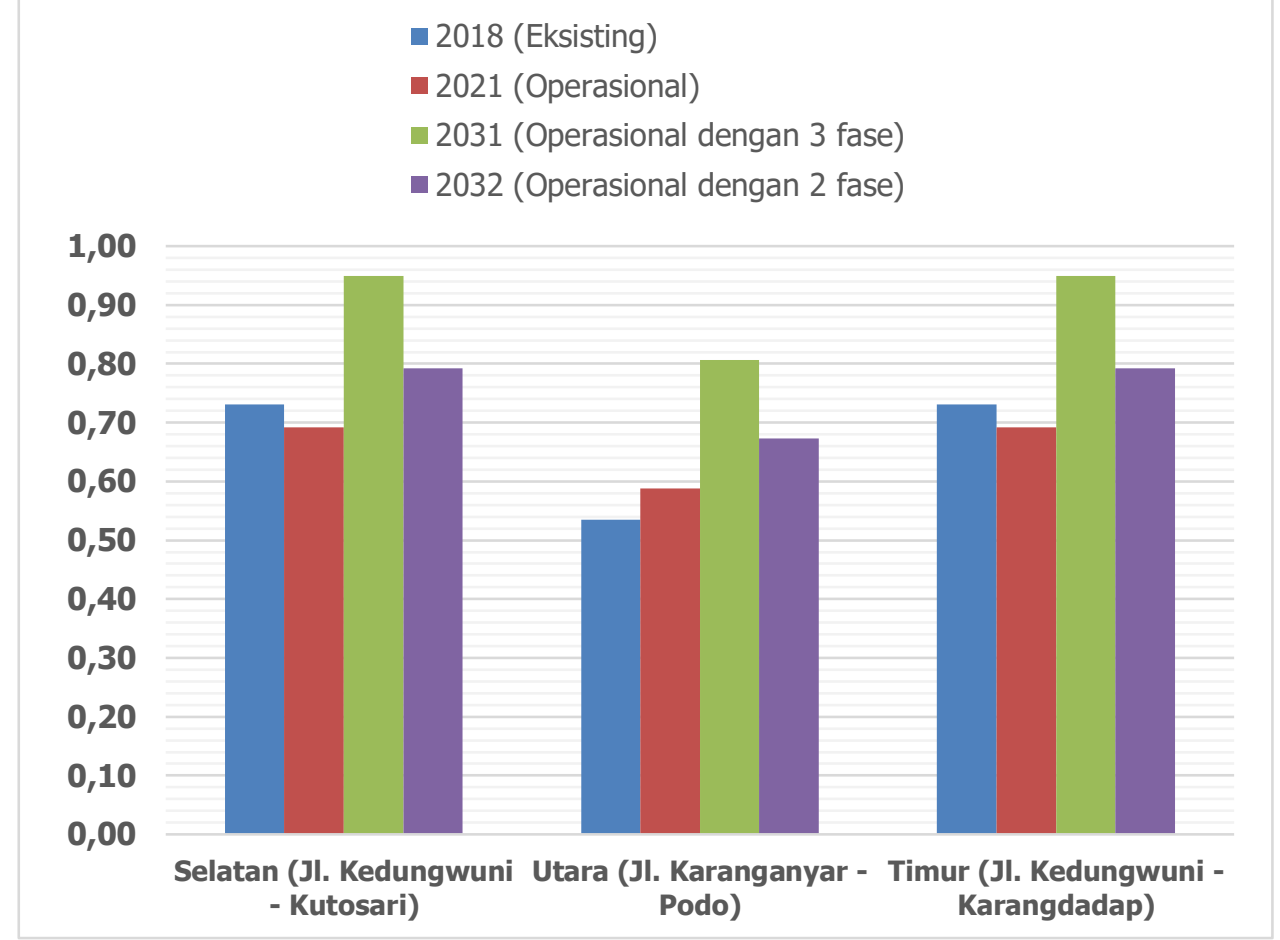

Gambar 12. Perbandingan Kinerja Derajat Kejenuha nSimpang Eks BCA

Berdasarkan hasil analisis diatas, dapat diketahui bahwa dalam perbandingan kinerja derajat kejenuhan di Simpang Eks BCA tahun operasional 2031 mengalami penurunan kinerja yang signifikan. Dengan demikian penanganan simpang dengan 3 fase diusulkan dirubah menjadi 2 fase untuk mengurangi derajat kejenuhan dan tundaan. Terlihat dengan simulasi penanganan 2 fase di Simpang Eks BCA pada tahun 2031 relatif efektif apabila dilakukan.

Sedangkan apabila dilihat berdasarkan geometric simpangnya, lebar pendekat pada Simpang Eks BCA saat tahap operasional akan menyesuaikan lebar ruas jalan terdampak, dalam hal ini adalah Jalan Kedungwuni - Kutosari sebagai lengan selatan, Jalan Karanganyar - Podo sebagai lengan utara dan Jalan Kedungwuni - Karangdadap sebagai lengan timur Simpang Eks BCA. Pada tahun 2021 dilakukan pelebaran ketiga ruas jalan tersebut sehingga mempengaruhi lebar pendekat pada Simpang Eks BCA. Secara rinci mengenai lebar pendekat pada Simpang Eks BCA dapat dilihat pada table berikut.

Tabel 30. Perbandingan Lebar Pendekat Simpang Eks BCA Berbagai Tahapan

\begin{tabular}{|l|c|c|c|}
\hline \multirow{2}{*}{\multicolumn{1}{|c|}{ Tahun }} & \multicolumn{3}{|c|}{ LebarPendekat (m) } \\
\cline { 2 - 4 } & Utara & Selatan & Timur \\
\hline 2018 (Eksisting) & 8 & 7 & 5,7 \\
\hline 2018 (Konstruksi) & 8 & 7 & 5,7 \\
\hline 2021 (Operasional) & 12 & 12 & 12 \\
\hline
\end{tabular}

